\title{
Nicodemus. A Disciple Liberated by the Cross of the Christ from the Darkness of Fear and Disbelief
}

\author{
ZBIGNIEW GROCHOWSKI \\ Faculty of Theology, Cardinal Stefan Wyszyński University in Warsaw \\ e-mail: zbigniewgrochowski@gmail.com \\ ORCID: 0000-0002-1785-5684
}

\begin{abstract}
Nicodemus, a Pharisee and one of the Jewish leaders, appears only in the Fourth Gospel. Three events in which he participates - a night meeting with Jesus (John 3:1-21), a verbal clash with members of the Sanhedrin (John 7:50-52) and a funeral, performed for Jesus together with Joseph of Arimathea (John 19:38-42) - are perceived negatively by numerous exegetes, and Nicodemus's attitude is (sometimes harshly) criticised. However, taking into consideration the significance of all the details of the current narrative and the context of the occurring events, one should be led to the conclusion that this man, nowhere explicitly referred by the Evangelist with the term $\mu \alpha \theta \eta \tau \eta \dot{s}$, deserves to be called "a disciple of Christ," who passed through the three-stage process of maturation in faith. Gradually he began to gain courage in advocating for Christ, and at the decisive moment - during Jesus' death on the Cross - he definitely stepped out of hiding and gave a public testimony of his adherence to the Master of Nazareth. His person, through a gesture shown to the Crucified, became the locus theologicus in which Jesus revealed himself as the immortal Messiah, Prophet, and King.
\end{abstract}

Keywords: Nicodemus, discipleship, cross, witness, conversion

\section{Introduction}

The figure of Nicodemus has fascinated many a reader of the Gospel of John. ${ }^{1}$ For, when one reads the pericopes that present the man $(3: 1-21 ; 7: 45-53 ; 19: 38-42)$, several instances of uncertainty arise: 1) Did Nicodemus really exist? The question seems valid particularly because there are no mentions of him in the synop-

1 This article takes some content from the monograph: Z. Grochowski, Il discepolo di Gesù nell'ora della prova (Gv 18-19), luogo di rivelazione del Maestro (Studia Biblica Lublinensia 13; Lublin: Wydawnictwo KUL 2015). It is, however, thoroughly revised and updated, and provides new arguments. Thanks to the English version, the author's view of Nicodemus is now available to all readers, especially those for whom the Italian language may be an insurmountable barrier. 
tic Gospels. ${ }^{2}$ Could it be, then, that St John created the character on the basis of some person present, for instance, in the Jewish tradition? 2) Is his attitude commendable, or should it be perceived negatively, as a large number of exegetesnowadays especially — continues to see him? ${ }^{3} 3$ ) What was the motivation behind Nicodemus's involvement in the preparation of the burial of Christ? What was the extent to which he was obliged to perform that deed? 4) Was the burial, such as that of Christ - sumptuous and costly as it was - offered to every other Jew (cf. 19:40)? And hence: does the dignitary's gesture convey an inherent symbolical message? What did Nicodemus want to express thereby? What is its possible relation to the revelation of Jesus? What theological aspects of the Fourth Gospel is Nicodemus's attitude aligned with? 5) Was the fact that Jesus had been buried as near to the place of the crucifixion as possible merely due to "the Jewish day of Preparation" (cf. 19:42), or was there more to it than that? In other words, was the haste of Nicodemus and Joseph's proceedings in order to perform the interment before the sunset in any way related to the author's remark that Nicodemus was "the man who (had) visited Jesus at night" - 3:2 (19:39)?

These and other potential questions prompt one to reinvestigate the matters related to Nicodemus. Admittedly, there is vast literature discussing the individual (and in a subsequent section of the paper, particular works and their authors will be presented alongside a review of various opinions regarding Nicodemus. It will constitute a status quaestionis of sorts for this article, albeit somewhat atypical, for not situated in the opening of the text). However, what proves most surprising is such significant divergence in the opinions expressed about Nicodemus. Particularly puzzling is the critical opinion of some scholars of such a seemingly positive gesture, as giving Jesus a solemn and dignified burial.

This study will therefore aim to revise the exegetes' evaluations of Nicodemus and provide another assessment, based on new premises. In the process, we will submit an original interpretation of the plural form oí $\delta \alpha \mu \varepsilon v$ ("we know") in 3:2. We are also intending to emphasise the role that the Cross-as the instrument of Christ's exaltation - played in the moment culminating the process of

2 The issue is particularly intriguing because of Nicodemus's appearance in the account of the Passion (John 19), for that narrative exhibits a greater number of similarities between the Fourth Gospel and the synoptics. Cf. E. Florit, Il metodo della "storia delle forme" e sua applicazione al racconto della Passione (Roma: Pontificio Istituto Biblico 1935) 166; S. Cipriani, "La questione giovannea. La singolare fisionomia del cosiddetto "Vangelo spirituale»," Cento problemi biblici (eds. G. Bressan et al.) (Assisi: Pro Civitate Christiana 1962) 312-313; F. Gryglewicz, "Męka Chrystusa Pana w badaniach ostatnich dziesięciu lat," $A K$ 63/1 (1971) 168; A. Vanhoye, "Opisy Męki w Ewangeliach synoptycznych,” Męka wedlug czterech Ewangelii (eds. A. Vanhoye et al.; trans. E. Romanek) (Kraków: Kairos 2002) 17.

3 R.A. Culpepper, "Nicodemus: The Travail of New Birth," Character Studies in the Fourth Gospel. Narrative Approaches to Seventy Figures in John (eds. S.A. Hunt - D.F. Tolmie - R. Zimmermann) (WUNT 314; Tübingen: Mohr Siebeck 2013) 251: "Over the past forty years, interpreters have turned repeatedly to ambiguity as the byword for Nicodemus's role in John." 
Nicodemus's ascending from the darkness of fear and disbelief. Another goal of the work will be to identify the function that Nicodemus performs in St John's narrative. Finding answers to the above questions will greatly assist us in reaching solution to the latter issue.

The title of this study, pointing among other things to "the Cross of the Christ," evokes the events described in the final section of St John's work. And it is these events that will receive most of our attention. However, the author of the Gospel, describing Jesus' burial, reminds his readers of the first, nighttime meeting in Jerusalem between the "Jewish dignitary, Pharisee" and the "Rabbi" of Nazareth, presented in the opening of the book (3:1-2). He does so by making a retrospective comment: "He was accompanied by Nicodemus, the man who earlier had visited Jesus at night" (19:39a). Seeing another similar comment by the author- "Nicodemus, who had gone to Jesus earlier" (7:50) — it is not difficult to conclude that all three instances in which we encounter the figure we are interested in here constitute a series of interconnected events. The Evangelist's remarks calling back to prior events implicitly suggest that all the scenes featuring Nicodemus be interpreted as a single whole.

Therefore, the "liberation of the disciple from the darkness of fear and disbelief" [4], signalled in the title of the paper, will be preceded by a presentation and a commentary of Nicodemus's entire way described by the Fourth Evangelist, starting from the nocturnal meeting of the two men in John 3 [2], through Nicodemus's reaction to the words of the priests and Pharisees in John 7 [3], all the way to the Calvary and Jesus' tomb (John 19) [4]. These analyses will be prefaced by a search for a potential prototype of the figure of Nicodemus in extra Biblical Jewish literature [1]. Whereas all the outlined inquires will culminate in the presentation of the final conclusions.

The article will benefit from a synchronic approach to the Biblical text, with the use of elements of the methods applied in intertextual, narrative and rhetorical analyses. The Gospel of John narrates events and cites dialogues; therefore, it will come as a perfectly reasonable development that there will occur some references to the tenets of narrative criticism. Our contribution to the state of research on Nicodemus will include the mention and use of the telling \& showing technique, valuable as a means to characterise his identity of a (potential) disciple. A novum of sorts will also include the use of tools and terminology native to classical rhetorics, owing to which some rhetorical devices present in St John's narrative will be defined. ${ }^{4}$ Of assistance will also be the method of referring back to the traditions of rabbinic interpretations. Additionally, psychological approach

4 Cf. K. Kłósek, "Metoda analizy narracyjnej," Metody interpretacji Nowego Testamentu. Wprowadzenie (R. Bartnicki - K. Kłósek) (Kraków: Petrus 2014) 241-242: "Figury retoryczne". 
to the Bible will be presented in order to describe the hypothetical emotional and intellectual experiences of Nicodemus. ${ }^{5}$

\section{1. "Nicodemus" in Extra Biblical Jewish Literature}

In Greek culture, "Nicodemus" is a common name (Nıкó $\eta \eta \mu \varsigma)$, meaning: "the one who defeats the people" or "the people who triumph / triumphant people." It was adapted by Jews, who expressed it in a transcribed form of Naqdîmôn / Naqdêmôn. It turns out, however, that it did not enjoy much popularity among the members of God's chosen people. ${ }^{7}$ This opinion retains its validity at least regarding the times of the New Testament. An Israeli scholar, Tal Ilan, states in her monumental work presenting the result of her research on the occurrence of Jewish names between $330 \mathrm{BCE}$ and $200 \mathrm{CE}$ that — besides the figure in the Gospel of John - there are only three other Nicodemuses: 1) Nıко $\mu$ í $\eta \varsigma$, the father of Gu-

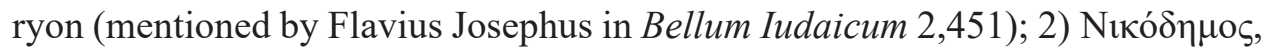
an ambassador of Aristobulus (mentioned by Flavius Josephus in Antiquitates Iudaicae 14,37); and 3) Naqdîmôn bēn Gûriôn. ${ }^{8}$ The latter on the list appears in some talmudic tractates (bGit 56a; bKet 66b; bTaan 19b-20a) as a man of a Galilean origin, affluent and generous citizen of Jerusalem, who during the siege of the Holy City in $70 \mathrm{CE}$ provided its inhabitants with water. ${ }^{9}$ The question arises: would it be possible to identify him as the Nicodemus present in the pages

5 A technical note: biblical sigla with no indication of the book in the Scripture all refer to the Gospel of John.

6 Cf. R. Vignolo, Personaggi del Quarto Vangelo. Figure della fede in San Giovanni, 2 ed. (Milano: Glossa 2006) 98; J.H. Thayer, A Greek-English Lexicon of the New Testament Being Grimm's Wilke's Clavis Novi Testamenti, 24 ed. (Grand Rapids, MI: Baker Book 1999) 426; R. Metzner, Die Prominentenim Neuen Testament. Ein prosopographischer Kommentar (SUNT 66; Göttingen: Vandenhoeck \& Ruprecht 2008) 299.

7 Cf. R. Bauckham, "Nicodemus and the Gurion Family," The Testimony of the Beloved Disciple. Narrative, History, and Theology in the Gospel of John, 3 ed. (ed. R. Bauckham) (Grand Rapids, MI: Baker Academic 2009) 152 with f.n. 65. The misguided opinions on the matter presented in three commentaries to the Gospel of John, that by Rudolf Bultmann, Raymond E. Brown, and Craig S. Keener - reasonably refuted by Richard Bauckham - may be extended by a list of other "authorities," such as: W. Bauer - F.W. Danker - W.F. Arndt - F.W. Gingrich, A Greek-English Lexicon of the New Testament and Other Early Christian Literature, 3 ed. (Chicago, IL - London: University of Chicago Press 2000) 673, as well as J.H. Moulton - G. Milligan, The Vocabulary of the Greek Testament. Illustrated from the Papyri and Other Non-Literary Sources (Grand Rapids, MI: Eerdmans 1976) 427.

8 T. Ilan, Lexicon of Jewish Names in Late Antiquity. I. Palestine 330 BCE - 200 CE (TSAJ 91; Tübingen: Mohr Siebeck 2002) 298-299.

9 Cf. Vignolo, Personaggi, 98. 
of the Fourth Gospel? ${ }^{10}$ Or at least, should not one consider the hypothesis that Naqdimôn bèn Gûriôn, who by his prayer caused the longed-for rain to fall upon Jerusalem, only for the sun to subsequently return, might have been a "homonym" of the character from the Gospel of John and the prototype that inspired the Fourth Evangelist to create the figure in his work? Of importance indeed prove some of his characteristics: a wealthy man, concurrently generous in his charity, going by the same rare name, and a member of the Sanhedrin. ${ }^{11}$

However, among the difficulties encountered in the process of identifying these personages the first to emerge is the chronological one. The Talmudic Nicodemus at the time of Jesus' public activity (ca. 28-30 CE) would be no more than 30 years old, which seems too young an age to deserve to be called a "Jew-

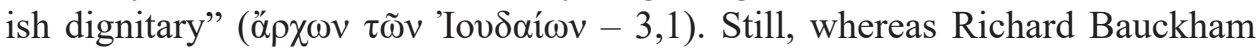
claims that the identification of both Nicodemuses is groundless, ${ }^{12}$ Zeev Safrai maintains that such eventuality cannot be ruled out with complete certainty. ${ }^{13}$

Another challenge is posed by the origin of both characters. Rabbinic literature points to Galilee as the birthplace of Nicodemus, the son of Guryon ${ }^{14}$; meanwhile, what transpires from the text of the Fourth Gospel is that John's Nicodemus was not a Galilean. The question: "You aren't from Galilee too, are you?" (7:52) opens with the particle $\mu$ ', requiring the interlocutor to answer in a negative way. ${ }^{15}$ The narrative context also suggest such response: had Nicodemus been from Galilee, his colleagues (who no doubt knew him well) would not have addressed him in such a manner. This rhetorical question besides expressing

10 D. Flusser - R.S. Notley, The Sage from Galilee. Rediscovering Jesus' Genius, 4 ed. (Grand Rapids, MI - Cambridge: Eerdmans 2007) 140, do not hesitate to treat both these characters as a single figure.

11 Cf. Z. Safrai, "Nakdimon b. Guryon: A Galilean Aristocrat in Jerusalem," The Beginning of Christianity (eds. J. Pastor - M. Mor) (Jerusalem: Yad Ben-Zvi Press 2005) 300, 310, 314.

12 Bauckham, "Nicodemus," 167. In a similar vein: S. Mendner, "Nikodemus," JBL 77 (1958) 293-323.

13 Safrai, "Nakdimon," 310.

14 Safrai, "Nakdimon," 305-306, and f.n. 22.

15 Cf. F.W. Gingrich, Shorter Lexicon of the Greek New Testament, 2 ed. (revised by F.W. Danker) (Chicago, IL - London: University of Chicago Press 1983) 127: " $\mu \eta$. . . as an interrogative particle when a negative answer is expected"; H.W. Smyth, Greek Grammar (Cambridge, MA: Harvard University Press 1984) 598 (§ 2651): “ $\mu \eta$. . . expect[s] the answer no"; F. Blass - A. Debrunner - F. Rehkopf, Grammatik den neutestamentlichen Griechisch, 17 ed. (Götingen: Vandenhoeck \& Ruprecht 1990) 355 (§ 427,2): “ $\mu \eta ́$ ( $\left.\mu \dot{\eta}_{\imath \iota}\right)$, wenn eine verneinende Antwort erwartet wird”; H.G. Liddell - R. Scott H.S. Jones - R. McKenzie, A Greek-English Lexicon. With a Revised Supplement (Oxford, NY: Clarendon 1996) 1124: " $\mu \eta$. . . § C (in questions) I. (direct questions) a. with indicative, implying a negative answer, surely not, you don 't mean to say that"; B. Friberg - T. Friberg - N.F. Miller, Analytical Lexicon of the Greek New Testament (Grand Rapids, MI: Baker Books 2000) [CD-ROM]: “ $\mu \eta$. . . used to introduce questions expecting a negative answer (cf. 1Co 12,29-30)"; Thayer, Lexicon, 408:

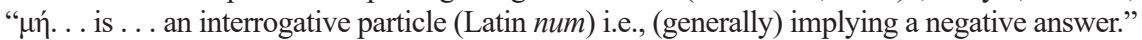


mere disdain for Jesus, a Galilean discussed at that moment, at the same time points to non-Galilean origin of Nicodemus. ${ }^{16}$

Hypotheses have been put forward pointing to a potential kinship between John's Nicodemus and the Nicodemus of rabbinic literature, i.e., the son of Guryon, and hence either that between a grandfather and a grandson or that between an uncle and a nephew. ${ }^{17}$ However, without any irrefutable arguments for the identification of both figures and taking into consideration the discrepancies existing within the Jewish literature, we are willing to accept as valid the opinion expressed by Safrai, when he states: "The central argument ... is not that all these events actually occurred . . . nor . . . the question of whether Jesus did indeed meet Nakdimon ... [T] he narratives [the Fourth Gospel and the Talmud] reflect [rather] an actual historical memory of a Jerusalem leader and philanthropist. This is not a precise history ... but a popular memory with realistic elements." 18

\section{Nighttime Encounter between Nicodemus and Jesus (John 3:1-21)}

The first encounter between the two men took place in the context of the signs performed by Jesus in Jerusalem $(2: 23 ; 3: 2)$. Nicodemus came to Jesus "at night." The circumstance was diversely interpreted: either as an expression of secretive nature of Nicodemus's interest in Jesus ${ }^{19}$, or even as the former's fear of being discovered ${ }^{20}$ Roberto Vignolo, referring to other authors, adds further possible motivations of the nocturnal meeting: "in order to have a conversation that would be uninterrupted (Lagrange), quiet (Delling); or because night evokes the mystery (Bultmann). However, the most plausible explanation," according

16 It is well pointed out i.a. by Safrai, "Nakdimon," 306, f.n. 25, when he remarks: "Linguistically, it would be easier to interpret the question of the elders as a statement «but you are not from Galilee»."

17 J.A.T. Robinson, The Priority of John (London: SCM 1985) 287; Bauckham, "Nicodemus," 34.

18 Safrai, "Nakdimon," 311. The challenge that John's Nicodemus is a purely fictitious creation is rejected by i.a.: J. Hastings et al. (eds.), A Dictionary of the Bible. Dealing with Its Language, Literature, and Contents Including the Biblical Theology. III. Kir-Pleiades (Edinburgh: Clark 1904) 543; M.C. Tenney, "The Gospel of John," The Expositor's Bible Commentary. With the New International Version of the Holy Bible. IX. John-Acts (eds. F.E. Gaebelein - J.D. Douglas) (Grand Rapids, MI: Zondervan 1981) 186; R.E. Brown, The Death of the Messiah. From Gethsemane to the Grave. A Commentary on the Passion Narratives in the Four Gospels (New York et al:: Doubleday 1994) II, 1279. Meanwhile, Siegfried Mendner's view of the matter proves stronger still, "Nikodemus," 293: "the historicity of Nicodemus is not to be questioned."

19 A.T. Lincoln, The Gospel According to Saint John, 2 ed. (BNTC 4; Peabody, MA: Continuum 2006) 484; J. Zumstein, L'évangileselon saint Jean (1-12) (CNT 4a; Genève: Labor et Fides 2014) 113.

20 F.J. Moloney, The Gospel of John (SP 4; Collegeville, MN: Liturgical Press 1998) 510; S. Grasso, Il Vangelo di Giovanni. Commento esegetico e teologico (Roma: Città Nuova 2008) 145. 
to Vignolo, "is Nicodemus's diffidence . . . . Moreover: nighttime was when one could study the Torah at peace («[Blessed is the man who] in his Law doth meditated day and night!» Ps 1:2b, cf. Josh 1:8)." ${ }^{21}$ The latter interpretation finds corroboration in the practice of nighttime reading of Biblical texts, attested to both in the scrolls of Qumran (see 1QS 6:6-7) and in rabbinic literature. ${ }^{22}$ Nevertheless, the apprehension of the threat from the Jews appears to be the most valid explanation. Such reading is suggested not only by the temporal circumstances ("at night" - 3:2), but also - in a later section of the Gospel—by a parallel designation of Joseph of Arimathea as "a secret disciple" (19:38), as well as the narrator's remark that "many even among the leaders believed in him, but because of the Pharisees they would not openly acknowledge their faith for fear they would be put out of the Synagogue" (12:42).

Hence, Nicodemus's attitude is marked by an inherent tension; a contrast between "coming to Jesus" (the act of a beginner in faith) and doing it "at night" (i.e. in a counterpoise to Jesus, who is "the Light" - cf. 8:12, 9:5, 12:46), rendering the situation ambiguous and ultimately improper. ${ }^{23}$ Despite the fact that he opens his discourse with a captatio benevolentiae ${ }^{24}$ of sorts, which includes the titles of "Rabbi" and "Teacher," ascribed to Jesus (3:2a), it does not point to Nicodemus's "(complete) commitment of a disciple." We acknowledge the omission of the article before the noun $\delta 1 \delta \alpha \sigma^{\prime} \alpha \alpha \lambda \mathrm{os}:$ "not the Master, but (broadly

21 Vignolo, Personaggi, 99-100.

22 H.L. Strack - P. Billerbeck, Kommentar zum Neuen Testament aus Talmud und Midrasch. II. Das Evangelium nach Markus, Lukas und Johannes und die Apostelgeschichte. Erläutert aus Talmud und Midrasch, 3 ed. (München: Beck 1961) 420, list texts that directly recommend nocturnal study of the Torah.

23 Vignolo, Personaggi, 100. St Augustine, as cited in: A. Marchadour, I personaggi del Vangelo di Giovanni. Specchio per una cristologia narrativa (ed. A. Filippi; trans. R. Pusceddu) (Bologna: Dehoniane 2007) 64, interprets the event in a more negative light: "Nicodemo . . . si reca dal Signore, e vi si reca di notte; si accosta alla luce, ma la cerca nelle tenebre . . . Parla ancora come chi è nelle tenebre della sua carne . . . Non capisce ciò che gli dice il Signore, non capisce ciò che gli dice la Luce." Even more critical is Mary M. Pazdan ("Nicodemus and the Samaritan Woman: Contrasting Models of Discipleship," BTB 17 [1987] 146), who claims: "given the symbolic dark / light dichotomy ... Nicodemus represents a group who does not accept Jesus". On the other hand, Winsome Munro ("The Pharisee and the Samaritan in John: Polar or Parallel?," CBQ 57 [1995] 716) seems to be vindicating Nicodemus, when he writes: "in hiding his visit to Jesus, Nicodemus is in good company. Jesus also hides! [cf. 7:3-9; 8:59; 11:54-57; 12:36b] . . Yet Jesus' receiving him clearly places him in a different category, that of one who can be trusted." Undoubtedly, one has to differentiate between the motivation behind Jesus' hiding (i.e. His "elusiveness" in verses 7:30, 8:20.59, 10:39, 11:54; cf. M.W.G. Stibbe, "The Elusive Christ: A New Reading of the Fourth Gospel," JSNT 44 [1991] 20-25 and J.H. Neyrey, The Gospel of John [New Cambridge Bible Commentary; Cambridge: Cambridge University Press 2007] 15) and that of Nicodemus. A more balanced interpretation, one that could be placed alongside the above-mentioned commentaries alluding to St John's symbolism, can be found in J.L. Resseguie, The Strange Gospel. Narrative Design and Point of View in John (BibInt 56; Leiden - Boston - Köln: Brill 2001) 120: "Nicodemus is not hostile to the light; he simply does not comprehend the light."

24 Metzner, Prominenten, 303, f.n. 20. 
speaking) a master, who has been (generally) sent by God, like so many of His other emissaries in the past." ${ }^{25}$ Admittedly, however, one must underscore both the significance and the emphatic position of the phrase à $\pi$ ò $\theta \varepsilon$ ov ("from God") in the sentence $\dot{\alpha} \pi \hat{o} \theta \varepsilon \sigma \tilde{\varepsilon} \dot{\varepsilon} \lambda \hat{\eta} \lambda v \theta \alpha \varsigma \delta 1 \delta \alpha ́ \sigma \kappa \alpha \lambda \circ \varsigma$ ("you are a teacher who has come from God"). ${ }^{26}$ Thus, the textual material is not ultimately irreconcilable with a perception of Nicodemus as a man who does experience a kind of spiritual and / or intellectual "attraction" to Jesus, a sense of being intrigued by the Master of Nazareth. In light of 9:16.31-34, one could see Nicodemus's words "For no one could perform the signs you are doing if God were not with him" ( $3: 2 b)$ even as a profession of faith, albeit an implicit one. ${ }^{27}$ We could even venture a hypothesis that he is among those who "believed in Jesus' name," having seen the signs that He had performed in Jerusalem (2:23). It would correspond to the already-cited commentary by the Evangelist: "many even among the leaders believed in him, but because of the Pharisees they would not openly acknowledge their faith for fear they would be put out of the Synagogue" (12:42). On such view, Nicodemus — one of the "leaders" (3:2)—would be one of those who believed in Jesus (though originally in an atmosphere of apprehension), or at least who started to take Jesus and His teaching seriously.

The plural form of the verb ot $\delta \alpha \mu \varepsilon v$ ("we know" - 3:2a) tends to be interpreted in a series of ways. For some, Nicodemus is a representative of the leaders of the people, a group that he himself was a member of $(3: 1) .{ }^{28}$ For others, he

25 Cf. Vignolo, Personaggi, 102; J.-M. Auwers, "La nuit de Nicodème (Jean 3:2; 19:39) ou l'ombre du langage," $R B 97$ (1990) 490.

26 Cf. G. Renz, "Nicodemus: An Ambiguous Disciple? A Narrative Sensitive Investigation," Challenging Perspectives on the Gospel of John (ed. J. Lierman) (WUNT 2/219; Tübingen: Mohr Siebeck 2006) 261 and f.n. 29.

27 Is Nicodemus not among the number of Pharisees who in 9:16 abstained from rejecting Jesus? What is more, the man healed from blindness was expelled from the Synagogue precisely for words much like those uttered by Nicodemus (9:31-34).

28 Cf. L.C. Boughton, "The Priestly Perspective of the Johannine Trial Narrative," RB 110 (2003) 535; F. Manns, Ecce Homo. Una lettura ebraica dei Vangeli (Torino: Lindau 2011) 74; J. Clark-Soles, "Characters Who Count: The Case of Nicodemus," Engaging with C.H. Dodd on the Gospel of John. Sixty Years of Tradition and Interpretation (eds. T. Thatcher - C.H. Williams) (New York - Cambridge: Cambridge University Press 2013) 134. M.R. Whitenton, "The Dissembler of John 3: A Cognitive and Rhetorical Approach to the Characterization of Nicodemus," JBS 135 (2016) 153, besides claiming that Nicodemus had been sent "to investigate [Jesus] on behalf of the Jewish religious establishment," adds that he came to Jesus as a "suspicious dissembler." As his starting point, he chose the comment made by the Evangelist in 2:24-25 and the hypothesis stemming therefrom, according to which Jesus was persuaded as to Nicodemus's ill-will. The exegete further elaborates this idea in his monograph Configuring Nicodemus. An Interdisciplinary Approach to Complex Characterization (LNTS 549; London: Clark 2019). Meanwhile, Resseguie, Strange Gospel, 121, puts forth a slightly different interpretation that underscores (solely) personal conviction of the character as to being the representative of the entire group. 
represented the people celebrating Passover in Jerusalem, mentioned at 2:23. ${ }^{29}$ Others still, believe that his disciples accompanied him when he came to meet Jesus, who was also surrounded by a group of his own disciples. ${ }^{30}$ Some exegetes treat the plural of "we know" as an indication of Nicodemus's politeness and civility. ${ }^{31}$ Meanwhile, the diachronic interpretation sees the Nicodemian ot $\delta \alpha \mu \varepsilon v$ as the voice of the Synagogue, entering into a dialogue with the Johannine community. ${ }^{32}$ We believe it to be an instance of the so-called pluarlis modestiae. ${ }^{33}$ Nicodemus, while trying to appear as a spokesperson for others, in fact voiced his own opinions. He intended to hide from Jesus the fact that it was indeed himself who had been interested in the new $\rho \alpha \beta \beta$, for he did not feel entirely certain of Him. Moreover, in the case of potentially being verbally "assaulted" by Jesus (or at least asked an inconvenient question), he would be able to deflect it, claiming

29 Cf. Vignolo, Personaggi, 102; W.M. Meeks, "The Man from Heaven in Johannine Sectarianism," The Interpretation of John (ed. J. Ashton) (IRT 9; Philadelphia, PA: Fortress - London: SPCK 1986) 149; Renz, "Nicodemus," 262; J.-M. Sevrin, "The Nicodemus Enigma: The Characterization and Function of an Ambiguous Actor of the Fourth Gospel," Anti-Judaism and the Fourth Gospel. Papers of the Leuven Colloquium 2000 (eds. R. Bieringer - D. Pollefeyt - F. Vandecasteele-Vanneuville) (Jewish and Christian Heritage 1; Assen: Royal Van Gorcum 2001) 359.

30 Cf. F.P. Cotterell, "The Nicodemus Conversation: A Fresh Appraisal," ET 96 (1985) 238; C. Bennema, "Nicodemus: In the Twilight Zone," Encountering Jesus. Character Studies in the Gospel of John, 2 ed. (ed. C. Bennema) (Minneapolis, MN: Fortress Press 2014) 150.

31 Cf. R. Schnackenburg, Das Johannesevangelium. I. Einleitung und Kommentar zu Kap. 1-4 (HThKNT 4/1; Freiburg - Basel - Wien: Herder 1965) 380 and Metzner, Prominenten, 303.

32 M. de Jonge, "Nicodemus and Jesus: Some Observations on Misunderstanding and Understanding in the Fourth Gospel," BJRL 53 (1971) 348, f.n. 1 refers to the phenomenon as pluralis ecclesiasticus; cf. C.G. Lingad, The Problems of Jewish Christians in the Johannine Community (TGST 73; Roma: Pontificia Università Gregoriana 2001) 295 and P. Dschulnigg, "Nikodemus im Johannes evangelium," Studien zu Einleitungsfragen und zur Theologie und Exegese des Neuen Testaments. Gesammelte Aufsätze von Peter Dschulnigg (eds. B. Kowalski et. al.) (BTS 9; Leuven - Paris - Walpole, MA: Peeters 2010) 256.

33 Smyth, Greek Grammar, §§ 1008-1009: "Plural of Modesty - A speaker in referring to himself may use the first person plural as a modest form of statement"; cf. L. Cignelli-R. Pierri, Sintassi di grecobiblico (LXX e NT). Quaderno I. A. Le concordanze (SBFA 61; Jerusalem: Franciscan Printing Press $2003) \S 11,2 \mathrm{~b}$ and the studies referred to by the authors: J.H. Moulton - N. Turner, A Grammar of New Testament Greek. III. Syntax (Edinburgh: Clark 1998) 28; J. Mateos, El aspecto verbal en el Nuevo Testamento (StNTest 1; Madrid: Ediciones Cristiandad - Valencia: Institución S. Jerónimo 1977) § 65a and L. Cignelli, "La grecità biblica," LASBF 35 (1985) 212. During that nocturnal conversation other first- and second-person plural verbs are uttered by Jesus (3:11-12). In those cases we are rather dealing with pluralis maiestaticus and / or sociativus (cf. Cignelli - Pierri, Sintassi, § 11,2b vs Mateos, Aspecto verbal, § 65a); here is Nicodemus who, as Jesus' interlocutor, seems to be "representative in a twofold manner: physically, as the exponent of the Jews who believed in Jesus because of the signs he had performed in 2:23 . . , but stronger still universally as the figure identified with the readers" (Vignolo, Personaggi, 108). The plural forms in 3:11-12 are interpreted in a different vein by Ole J. Filtvedt (“Revisiting Nicodemus' Question in John 3:9," JTS 70 [2019] 133, 136): "3:11 is designed to echo and ape $3: 2$... What Nicodemus erroneously imagined that he knew about Jesus, Jesus now claims that he alone knows . . Jesus is the one who testifies in 3:11 about himself ... [I]n 3:12 Jesus continues to emphasize the limits of Nicodemus's knowledge . . . as a critique of Nicodemus's pretension to know who Jesus was in 3:2." 
that he had not come on his own behalf, but as a representative of other leaders of the people. On such a reading, Nicodemus would seem to be not only someone experiencing fear of the Pharisees, but also a person apprehensive of / insecure with Jesus.

So far, the evaluation of Nicodemus's attitude has concerned particularly the realm of his emotions (i.e. his being intrigued by Jesus and concurrently afraid of either the Pharisees or Jesus becoming aware of the fact). Now, willing to turn to the intellectual sphere, one cannot but notice that the dialogue with Jesus bears marks of a certain difficulty Nicodemus has in understanding the meaning of the words uttered by his interlocutor $(3: 3-21) .{ }^{34}$ As a matter of fact, rather surprisingly and paradoxically, even though it was Nicodemus who came to Jesus and started their conversation, he soon withdrew from it, leaving all the room for the words uttered by Jesus. ${ }^{35}$ It may even be said that "Jesus, invited to a debate ... did not abide by the rules of the game. His strategy destabilised his interlocutor." ${ }^{36}$ Speaking of the necessity of "being reborn" of water and Spirit, Jesus presented Nicodemus with no small problem. ${ }^{37}$ Also the subsequent wordplay on the word "teacher" ${ }^{38}$ presented Nicodemus as a man who does not grasp Jesus's argument, being limited to the strictly physical and literal sense of the notions.

After the reflection on spiritual birth, Jesus continues his teaching and speaks of the necessity that the Son of Man be lifted up; of the need of believing in him; of the judgement awaiting those who do not believe in the name of God's Only Begotten Son; of those who hate the light that came into the world and hence chose the darkness and wrongdoings. ${ }^{39}$ Concerning Nicodemus, on one

34 Some exegetes believe the role of Nicodemus was "to show how some who were attracted to Jesus did not immediately understand him" (R.E. Brown, The Community of the Beloved Disciple [New York - Mahwah, NJ: Paulist Press 1979] 72, f.n. 128).

35 Resseguie, Strange Gospel, 121-122 and f.n. 39: "In 3:2, he speaks twenty-four words; in 3:4 eighteen words; and in 3:9 - his final speech — only four words . . . Jesus' speech expands . . . In 3:3, he speaks merely sixteen words, in 3:5-8, seventy words, and in 3:10-21, two hundred thirty one words (f.n. 39: Jesus' and the narrator's speech merge here)"; M. Michel, "Nicodèmeou le non-lieu de la vérité," RevSsRel 55 (1981) 230: "Jésus, eneffet, est le personnage dominant [en 3,1-21]." In a similar vein, A. Kubiś, "Uniwersalny wymiar miłości Boga według J 3,16,” VV 23 (2013) 130-132.

36 Marchadour, Personaggi, 65.

37 The adverb ơ $v \omega \theta \varepsilon v$ is semantically ambiguous: it can be translated as "from above," but also as "since the beginning" / "again" (cf. Resseguie, Strange Gospel, 122).

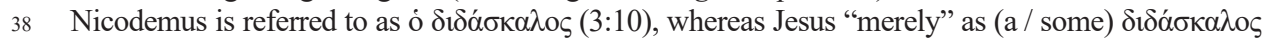
(3:2): "Nicodemo - non Gesù - pretende di essere il maestro, e, ciononostante, è un maestro che «non sa»" (Vignolo, Personaggi, 102).

39 We decided to recapitulate Jesus's speech with these words, because — as it turns out —all these motifs will return in the scene on Calvary, which Nicodemus will not only witness but also participate in: i.e. "the water" flowing from Jesus's side and "the Holy Spirit" bestowed upon those present at the cross $(19: 30.34$; cf. $3: 5 ; 7: 37-39)$; "faith" that leads to life $(19: 35 ; 20: 31 ; 21: 24)$; crucifixion $=$ the "exaltation" of Jesus and, lastly, the confrontation between the light and the darkness, (particularly striking in the scene of the capture: $18: 1-14$, but not only there), foretold already in the prologue (1:5). Cf. Z. Grochowski, “«Światłość w ciemności świeci i ciemność jej nie zaskoczyła 
hand he seems to have accompanied Jesus until the end of the pericope (3:21); on the other, however, we may feel that Nicodemus disappears from the scene of the Gospel already in 3:11 (for he does not react to any of his speaker's assertions). The nighttime encounter stops abruptly; it ends utterly unexpectedly, without a single comment on the potentially expected Nicodemus's response. ${ }^{40}$ "The colloquium ends in suspense."

\section{Nicodemus' Reaction to False Accusation of Jesus (John 7:45-53)}

Our protagonist appears for the second time in 7:45-53, where the Evangelist narrates the events that occurred during the feast of Tabernacles. Jesus teaches at the Temple (7:14), while on the final, most solemn day of the celebrations he proclaims the truth of the living water, the symbol of the Holy Spirit (7:37-39). The context for these words comprises the divisions among the crowds and the controversies among the Jews related to Jesus's teaching and the healing that he performed on Shabbat (7:21-23; cf. 5:8-9). The discussions also pertain to his messianic and prophetic status (7:25-27.40-44). Directly afterwards, the narrative outlines before our eyes the scene when the guards sent by the chief priests and Pharisees to arrest Jesus (7:30.44-45) express their admiration and awe of His words $(7: 46)$. The harsh reprimand received by the servants from their superiors (7:47-49) forces a reaction from Nicodemus, presented by the narrator's voice as the one "who had gone to Jesus earlier" (7:50b) - hence, it constitutes an explicit evocation of the nighttime encounter of both men of 3:1-21—with

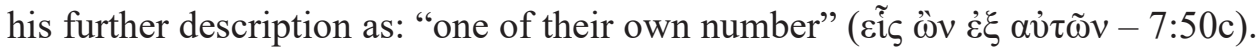
Thus, Nicodemus, even though he presents himself as someone "relatively close to sharing the point of view expressed by the guards who at 7:46 are unwilling to capture Jesus", ${ }^{42}$ at the same time is able to address the chief priests and Pharisees from a position of their peer in status and office. By no means does his utterance amount to an elaborate speech; it only comprises a single question, awaiting

/ nie przyłapała». Narracyjne uzasadnienie nowego thumaczenia J 1,5," StElb 17 (2016) 119-133; Z. Grochowski, "«Spirò» o piuttosto «consegnò lo Spirito»? La morte di Gesù e il dono del Paràclito presentati in Gv 19,28-30," StElb 19 (2018) 291-303.

40 Thus, the situation engenders diverse interpretation. Whereas W. Munro ("Pharisee," 725) writes: "Nicodemus's silence during the revelatory discourse in 3:1-21 denotes, at the very least, attentive and sympathetic listening"; Resseguie (Strange Gospel, 124) claims: "The narrative ends as it began with Nicodemus in darkness."

41 Vignolo, Personaggi, 108.

42 Vignolo, Personaggi, 110; Whitenton, Configuring, 112: "Nicodemus is starting to feel more at home with the crowds than with the Pharisees." 
his interlocutors to answer negatively: "Our law doesn't [ $\mu$ í] condemn a man unless it first hears from him and learns what he is doing, does it?" (7:51). It is a rhetorical question of the interrogatio / غ่ $\rho \omega ́ \tau \eta \mu \alpha$ category, aimed in this case at ascertaining an irrefutable fact. ${ }^{43}$ As it turns out, however, he will also be harshly refuted- - "They replied, "You aren't from Galilee too, are you? Investigate carefully and you will see that no prophet comes from Galilee!»” (7:52)—after which they all went home (7:53). Thus, the episode ends in a rapid break up of this short, dynamic dialogue, and silent departure of its participants.

\subsection{Negative Assessment}

For many exegetes, this situation resembles the nocturnal dialogue between Nicodemus and Jesus, which also ends in silence, with no words spoken by "the Jewish dignitary." That is why they spare no criticism directed against the person discussed here. Roberto Vignolo claims that Nicodemus "is a character in suspension, situated in no man's land. He is totally isolated: no longer does he belong to his own group (the leaders of the Pharisees). And - even though in his attitude to Jesus he is certainly nearer and more open to what we could observe before-it still manifests itself too faintly." ${ }^{44}$ In a later passage, the Italian exegete writes that one would expect Nicodemus to be more courageous ${ }^{45}$ in "his response against the brutal and destructive criticism levelled out by the Pharisees" and to express more explicitly his admiration for Jesus. ${ }^{46}$ Nevertheless, his intervention achieves no resolution. "Nicodemus continues to be marked by an internal tension, a testament to his indecision." ${ }^{\prime 7} \mathrm{R}$. Alan Culpepper adds: "His appearance ... carries some level of implication that he believes in Jesus, even if his response to the Pharisees stops short of a confession." 48 Furthermore, James Resseguie claims that "the Pharisee made some minor progress in the nar-

43 Cf. H. Lausberg, Retoryka literacka. Podstawy wiedzy o literaturze (trans. A. Gorzkowski) (Bydgoszcz: Homini 2002) 423 (§ 768): "Można wyróżnić kilka funkcji [One may distinguish several functions of] interrogatio: Quint[ilianus] IX, 2, 8: interrogamus etiam quo negari non possit ...."

44 Vignolo, Personaggi, 111.

45 Also Steven A. Hunt ("Nicodemus, Lazarus, and the Fear of «The Jews» in the Fourth Gospel," Repetitions and Variations in the Fourth Gospel. Style, Text, Interpretation [eds. G. van Belle et. al.] [BEThL 223; Leuven - Paris - Walpole, MA: Peeters 2009] 202) states that "Nicodemus timidly asks his colleagues," even though only a moment later he does acknowledge that "Nicodemus' question is not without risk" (emphasis added).

46 Cf. also Dschulnigg, "Nikodemus," 261: "Nikodemus auch an dieser Stelle noch als Personifikation jener Anführer der Juden sehen, die sich aus Furcht vor den Pharisäern und dem Synagogen aus schluß nicht offen zu Jesus bekennen."

47 Vignolo, Personaggi, 112; Whitenton, Configuring, 114: "he does so in a way that keeps him safe behind the veil of plausible deniability."

48 Culpepper, "Nicodemus," 257. 
rative 7:50-52." ${ }^{49}$ Meanwhile, for Jouette Bassler Nicodemus's attitude is merely an expression of his preoccupation with the Jewish Law (instead of his adherence to Jesus). ${ }^{50}$ Similarly, Urban von Wahlde does not read the Pharisee's words as pronounced in Christ's favour. ${ }^{51}$ Still more critical in his assessment, however, is Alain Marchadour: "Nicodemus seems to have failed to advance / transform through his discovery of Jesus. The two terms that qualify him in 3:1 (Pharisee and Jewish dignitary) reappear ... in 7:48. He persists in being a Pharisee ..., and it is the Law that has remained the point of reference for him ... [H]e continues to be one of them, still standing on the outside." ${ }^{52}$ In light of the question posed in 7:48 - "Have any of the rulers or of the Pharisees believed in him?"-Nicodemus has not believed in Jesus either. ${ }^{53}$ "Nicodemus's initial "belief" [2,23-3,1] ... [also now] appears anonymous or secret." ${ }^{54}$

\subsection{Positive Response}

In response to the above instances of negative evaluation of Nicodemus's attitude, we would most of all like to underscore the fact that passage 7:50-52 marks the first moment in the Gospel, when someone from the circle of religious leaders found the courage to publicly speak out in defence of Jesus and to express opinions in His favour. ${ }^{55}$ Additionally, in order to look at him in positive light and to properly understand Nicodemus's reaction, one has to take into consideration two aspects: denotation and connotation. ${ }^{56}$

Denotation refers to the meaning of the respective words and utterances, understood as existing in and of itself. In this case, it is not difficult to see that in his intervention, Nicodemus recalls a legal precept of the Torah, requiring for a person to be heard out, before they be judged (cf. Deut 1:16-17; 17:4; 19:16-18). This way, he faces his colleagues with a problem, which demands a specific decision: if someone is claiming to have been "sent" by God (7:28-29), he ought to be heard on matters he proclaims and deeds he performs (7:51). By refer-

49 Resseguie, Strange Gospel, 125.

50 J.M. Bassler, "Mixed Signals: Nicodemus in the Fourth Gospel," JBL 108 (1989) 640.

51 U.C. von Wahlde, The Gospel and Letters of John. II. Commentary on the Gospel of John (ECC; Grand Rapids, MI - Cambridge: Eerdmans 2010) 834.

52 Marchadour, Personaggi, 69-70. Cf. T.L. Donaldson, "Nicodemus: A Figure of Ambiguity in a Gospel of Certainty," Consensus 24 (1998) 123. In a similar vein Sevrin, "Nicodemus," 364: "Nicodemus as a character does not change [in John 7:50-52]."

53 Marchadour, Personaggi, 70.

54 Bennema, "Nicodemus," 153.

55 Filtvedt, "Revisiting," 121: "[Nicodemus] seems to be characterized in quite a positive way [in] 7:50."

56 Cf. A. Marchese, Dizionario di retorica e di stilistica. Arte e artificio nell' uso delle parole. Retorica, stilistica, metrica, teoria della letteratura, 5 ed. (Milano: Mondadori 1985) 63-64, 73. 
ring to the Torah, Nicodemus points to the right way and implicitly admits that the leaders' behaviour towards Jesus is improper. In a summary of Jesus' public activity, the Evangelist adopts a similar view; he cites the fundamental indictment put forth by Jesus: Jews failed to hear His words and consider His works (10:25-27.38;12:37-38); they transgressed against God's first commandment: "Hear, o Israel!" (Deut 6:4) and they neglected their obligation towards a prophet: "The Lord your God will raise up for you a prophet like me from among you, from your fellow Israelites. You must listen to him" (Deut 18:15). Fortunately, not all of them disregarded the legal norm and thanks to listening to Jesus' teaching were able to adhere to Him: "many even among the leaders believed in Him" (12:42), but only Nicodemus "one of their own number," found the courage to speak publicly. His reaction directs the attention of his colleagues to the word of the Law, situated at the origin of the conflict between them and Jesus: hearing. ${ }^{57}$

Connotation, on the other hand, pertains to a word or a sentence uttered in context and expresses its "additional meaning." ${ }^{58}$ By virtue of that, the legal regulation cited by Nicodemus acquires new meaning in the situation it was evoked in. Therefore, we should take a closer look at the context —in the passages before and after - of the words uttered by the discussed figure.

The preceding context involves, most of all, the unfriendly attitude of the leaders of the people, whose aggressive tone appears to be increasing in the first seven chapters of the Fourth Gospel, escalating as far as to the willingness to cause Jesus' death. ${ }^{59}$ Thus, the episode directly before Nicodemus's intervention acquires particular significance. On one hand, the leaders "cursed" "the mob that knows nothing of the Law" and indirectly also the guards who listened to Jesus' words with admiration (7:46-47.49); while on the other hand, by using a rhetorical question, they assume the attitude they represented to be the only right

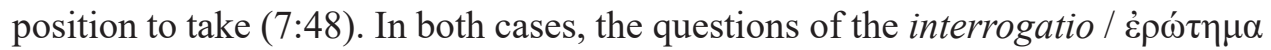
type-“You haven't been [ $\mu$ 'ं] deceived too, have you?"; "None [ $\mu$ '] of the rulers or the Pharisees have believed in him, have they?"- are intended as attacks on their interlocutors. ${ }^{60}$ This reprimand could indubitably further exacerbate Nico-

57 S. Pancaro, "The Metamorphosis of a Legal Principle in the Fourth Gospel. A Closer Look at John 7,51," Bib 53 (1972) 359-360.

58 Cf. Marchese, Dizionario, 63.

59 Therefore, it was not merely a matter of "ordinarily" persecuting Jesus (5:16), but of intending to downright murder Him (5:18; 7:1.19-20.25).

60 Cf. Lausberg, Retoryka, 422-423 (§ 767-768): “[Zapytanie] jest figurą, kiedy podejmowane jest nie po to, by się czegoś dowiedzieć, ale aby zaatakować: . . . «Dokąd to będziesz, Katylino, nadużywał naszej cierpliwości?» . . . [m]a o wiele więcej mocy niż proste stwierdzenie «Długo nadużywasz naszej cierpliwości»... [U]żywamy tej figury, gdy w oburzeniu pytamy o coś i wzmacniamy przez to swoją niechęć w stosunku do opisywanych rzeczy ... . Erotema jest zapytaniem wrogim wobec strony przeciwnej ... . Pytamy . . . ze względu na nienawiść . . albo gdy atakujemy". Moreover, a question of this category can be used as an exclamation. Cf. H. Lausberg, Elementi di retorica (trans. L.R. Santini) (Bologna: Mulino 1987) 246 (§ 445,2): “La «domanda retorica» (interrogatio . 
demus's sense of fear and inhibit his willingness to intervene in defence of Jesus. It was accompanied by a suspicion, verging on certainty, that Nicodemus would meet with a harsh reaction on the part of his peers. However, that intuition did not extinguish his courage. His reaction to transgression of the Law and unfair treatment of an accused man proved exemplary.

The context in the passage following the episode indicates that the answer given by the leaders to Nicodemus - "You aren't from Galilee too, are you? Investigate carefully and you will see that no prophet comes from Galilee!" (7:52) is expressed in the same tone of aggression and sarcasm. Following Stanisław Mędala, we may label their statement as a "double invective." It served to disguise their ill will and expressed their inability to listen to any other reason than their own. It consisted in "the accusation that [Nicodemus] was one of the Galileans pertaining to the moral sphere, for the Galileans living among pagans were considered by the Pharisees to be impure. The allegation of ignorance of the Law directed at a renowned Jerusalem teacher was [thus] aimed at the intellectual aspect." ${ }^{61}$ It turns out, however, that "the [E]vangelist uses irony with regard to the second charge, as it is the chief priests who have proven to be ignorant, as it is from Galilee, from the village of Gath-ha-Chepher (situated $4 \mathrm{~km}$ north-east of Nazareth) was where the prophet Jonah (2 Kgs 14:25) came from." ${ }^{62}$ Be that as it may, whoever opposes the stance taken by the Pharisees, runs a risk of being rejected and categorically condemned.

Thus, such a violent criticism levelled by Jewish dignitaries is pervasive both before and after Nicodemus's response. That is the context for his intervention in the case of Jesus. That is why, the opinion according to which Nicodemus was a man unable of giving the right (or, for that matter, any) answer to the Pharisees strikes us as rather surprising. ${ }^{63}$ It is them, who, cursing the mob (allegedly) ignorant of the Law, testify to the truth about themselves: by disregarding the precepts of the Torah, they situate themselves as those who are rejected by God, the cursed. However, the realisation that it was indeed the guards who admiringly listened to Jesus who did the right thing, whereas their superiors seem to have lost God's truth somewhere along the line, is supported by the contribution of Nicodemus - not only owing to the reference he makes to the precept of the Law, but also to the courage that made it impossible for him to remain silent in face of injustice and stand up for Jesus. There was no need for Nicodemus to answer the subsequent violent words spoken by the Pharisees. There is no way to

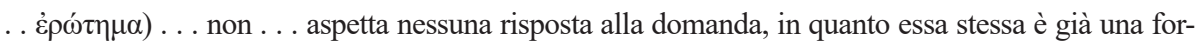
mulazione affermativa, prossima alla exclamatio."

61 S. Mędala, Ewangelia wedlug św. Jana. I. Rozdziały 1-12 (NKB.NT 4/1; Częstochowa: Edycja Świętego Pawła 2010) 655.

62 Mędala, Ewangelia, 655.

63 Vignolo, Personaggi, 111-112. 
peacefully investigate the truth with a hostile interlocutor. ${ }^{64}$ Concealing nothing, he voiced his own (and God's) truth adroitly (for also using rhetoric), leaving it to his compatriots to decide what to do with its message.

Lastly, we should also note the specific time of the events unfolding in John 7: it is the "feast of Tabernacles," in point of fact, its final, most solemn day (7:37). These were celebrations of joy and light.$^{65}$ This context marks a shrill contrast to the "nocturnal" circumstances of the encounter between Nicodemus and Jesus. This "disciple in statu crescendi" gradually steps out of the shadow to give an intrepid testimony, and adhere to Jesus. While regarding their initial conversation, we witness the Pharisee start to put into action the words that Jesus crowned that meeting with: "But whoever lives by the truth comes into the light, so that it may be seen plainly that what they have done has been done in the sight of God" (3:21). This marks a major step forward, "coming into the light," made by Nicodemus in the second episode presented on the leaves of the Fourth Gospel.

\section{Interment of Christ (John 19:38-42)}

For the third time, Nicodemus appears in St John's text in the scene of Jesus's funeral, which opens with a reference to Joseph of Arimathea and the account of the latter's initiative to bury the Crucified (19:38). ${ }^{66} \mathrm{He}$ asks Pilate to be allowed to take Jesus's body and receives his permission. A parallel text (Mark 15:43: $\tau o \lambda \mu \eta \dot{\sigma} \alpha \varsigma=$ "having mustered the courage") makes us realise that the act of appealing to the Roman Prefect with such a request was a move requiring boldness

64 In another vein, Bennema, "Nicodemus," 153: "the ferocious response of his colleagues in 7:52 may have robbed him of any courage to ally himself publicly with Jesus." The author refers to Nicodemus as "ambiguous" and likens him to the parents of the youth blind from birth, healed by Jesus (9:18-23). It should be noted, however, that in John 7 Nicodemus does speak out and thus behaves differently from them.

65 J.S. Kselman - M.L. Barré, "Psalms," The New Jerome Biblical Commentary (eds. R.E. Brown J.A. Fitzmyer - R.E. Murphy) (London: Geoffrey Chapman 2000) 547 (§ 34:136): “«O Yahweh . . shed your light upon us!»... The mention of the procession and branches brings to mind the feast of Tabernacles." Cf. 8:12 and Ps 118:27.

66 The name "Joseph" - as opposed to "Nicodemus" - enjoyed much popularity among Jewish men; cf. Ilan, Jewish Names, 150-157, 449. Additionally, L.Y. Rahmani (A Catalogue of Jewish Ossuaries in the Collections of the State of Israel [Jerusalem: The Israel Antiquities Authority - The Israel Academy of Sciences and Humanities 1994]) presents numerous testimonies drawn from funerary inscriptions containing the name yôsêf. He cites the following versions of the name, to be found in some of almost a thousand ossuaries owned by the modern state of Israel: 9.12.15.16.83.256.290.

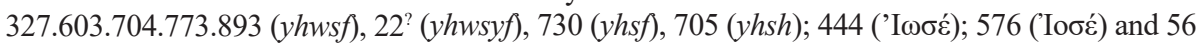

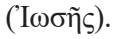


if not downright valiance. ${ }^{67}$ The following opinion expressed by Cook comes to our aid in answering the question whether it was at all possible to obtain a consent to be given the body, considering that Jesus had been charged with (alleged) "high treason" (crimen maiestatis): "it probably was a political execution, though not for maiestas, since Jesus was a peregrinus (i.e., not a Roman citizen) . . . Jesus was executed as a rebel . . . for sedition or troublemaking . . . [T] he narrative of Joseph of Arimathea's burial of Jesus [is] . . historically credible." ${ }^{98}$

\subsection{Was Nicodemus Jesus's Disciple?}

It may be worthwhile to take a closer look at the characteristics of Joseph of Arimathea, a member of the Council, ${ }^{69}$ particularly because some elements apparent therein precisely reflect components of the description of Nicodemus, also a member of the Sanhedrin, coming to Joseph's assistance. In 19:38-39, both men: (1) are identified by their names ("Joseph" / "Nicodemus"), (2) have their relationship and / or interaction with Jesus signalled ("a disciple of Jesus" / "the man who earlier had come to Jesus"), along with an indication (3) of an analogous manner these had come to be ("secretly" / "at night"), as well as (4) a presentation of similar deeds performed by both persons preparing the interment ("came", "took" / "came bringing"). The parallelism between the distinctive features of both figures makes us assume that the Evangelist might be suggesting that Nicodemus's nocturnal visit to Jesus might be somehow associated with Joseph's being "a disciple, but secretly." That conclusion would corroborate the hypothesis that Nicodemus had entered the path of discipleship of Christ already in $\mathrm{J} 3$, and experienced - as indicated in the episode in John 7-the process of growth and maturation in his new identity. Concurrently, the narrator's comment makes us aware that in the number of leaders of the people who came to believe in Jesus, but, because of the appetite for their own glory, failed to find the courage to admit it publicly (cf. 12:42-43), we ought also to count Joseph of Arimathea. However, at the moment of the funeral, as indicated by the concessive

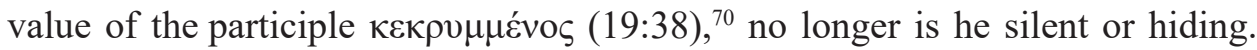

67 Cf. M. Flacius Illyricus, Glossa compendiaria in Novum Testamentum (Basileae: Perna \& Dietrich 1570) 459; J. Schlichting, Commentaria posthuma in plerosque Novi Testamenti libros (Irenopoli: Irenici Philalethii 1656) 139; C.S. Keener, The Gospel of John. A Commentary (Peabody, MA: Hendrickson 2003) 1161-1162 and f.n. 823; Tenney, "The Gospel of John," 186; K.E. Corley, "Women and the Crucifixion and Burial of Jesus," Forum 1 (1998) 216; Munro, "Pharisee," 725-726.

68 J.G. Cook, "Crucifixion and Burial," NTS 57 (2011) 197-199, 213.

69 The social status of Joseph is determined particularly in synoptic Gospels: a member of the Council

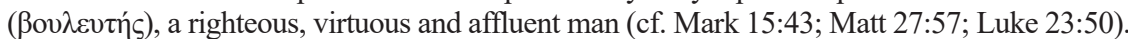

70 It has an adverbial function of concession: literally translated as "hidden," it assumes the meaning of "even though secretly." This grammar phenomenon is explained by philologists: E. De Witt Burton, 
By reversing the Evangelist's words, we are able to conclude that the moment came for Joseph to adhere to the love of God's glory more than to human glory: disregarding the expected backlash from the Sanhedrin, he went to Pilate and, having received permission, took the body of Jesus (19:38).

On the basis of not only the parallelism in the description of both men, but also of the claim provided in the following verse (19:40), that "they took the body of Jesus and wrapped it in linen cloths," an explicit expression of the fact they cooperated, we should also infer that in John 19 Nicodemus, too, assumes an attitude similar to that of Joseph's stepping out of concealment. Hence, one can safely say also about Nicodemus that he is leaving the domain of darkness, ever closer approaching the light (cf. 3:19-21). Especially that in John 19, another significant difference from the circumstances described in John 3 can be observed: whereas the first encounter between Nicodemus and Jesus occurred "at night," the funeral of the Master had to be carried out during daytime, before the sunset, according to the Jewish custom, defined in the Law: "If a person commits a sin punishable by death and is executed, and you hang the corpse on a tree, his body must not remain all night on the tree; instead you must make certain you bury him that same day, for the one who is left exposed on a tree is cursed by God. You must not defile your land that the Lord your God is giving you as an inheritance" (Deut 21:22-23). ${ }^{71}$ Both men decidedly step out of hiding and join efforts in order to publicly entomb the body of Jesus. ${ }^{72}$

Syntax of the Moods and Tenses in New Testament Greek (Edinburgh: Clark 1955) § 438; D.B. Wallace, Greek Grammar Beyond the Basics. An Exegetical Syntax of the New Testament with Scripture, Subject, and Greek Word Indexes (Grand Rapids, MI: Zondervan 1996) 634; A. Piwowar, Sktadnia języka greckiego Nowego Testamentu, 2 ed. (MPWB 13; Lublin: Wydawnictwo KUL 2017) 425 (§ 428). In the case of Joseph: even though he had been keeping his identity as disciple of Jesus hidden - and hence should not publicly act for the benefit of his Master - he did go to Pilate and requested to be given the Deceased's body.

71 Although the Romans were in the habit of leaving convicts crucified for many days after the execution, thus making them spoils for birds (adding to the dishonour), they nevertheless admitted exceptions, for instance: out of consideration for the religious sensibilities of the Jews. Cf. C. Mariano, Tetelestai. Il significato della morte di Gesù alla luce del compimento della Scrittura in Gv 19,16b-37 (QRivSR 14; Monopoli: Viverein 2010) 65, f.n. 72. The Italian exegete, besides quoting the biblical text, also refers to Josephus Flavius (Bellum Iudaicum 4,317). Similar is the approach of Jo-

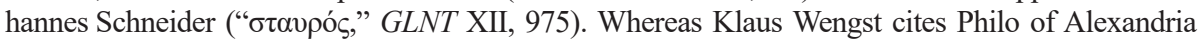
(In Flaccum, 83), mentioning an extremely rapid disposal and burial of bodies of the crucified to celebrate the Emperor's birthday (Il vangelo di Giovanni [Italian ed. G. Boscolo; trans. C. Danna] [Brescia: Queriniana 2005] 710). Cf. also: Pliny the Elder, Historia naturalis, 36.107; Lydus, De mensibus, 29; Eusebius, Historia Eccesiae, 5.1.41 and M. Hengel, Crucifixion. In the Ancient World and the Folly of the Message of the Cross (Philadelphia, PA: Fortress 1977) 87-88.

72 The Evangelist linked the motif of urgency of Christ's burial, required to be performed before the sunset, with the upcoming Shabbat, which — more importantly still—was "a great feast (Passover)" (cf. 19:14.31). In fact, the above-cited precept demanded that the crucified in Israel be buried straightaway (Deut. 21:22-23), but—as stated by R.E. Brown - "on special days there was greater pressure for observance" (Death, 1174). 
On several occasions, we have referred to Nicodemus (with some caution) as a "disciple," even though from the pair of men only Joseph of Arimathea is directly classified as such in the Gospels. ${ }^{73}$ That being so, are there grounds to the contention that Nicodemus also deserves the appellation? Being aware of the variety of narrative techniques helps one find the answer, one of which can be discovered in 19:38-42. It is called: telling \& showing. Resseguie provides an explanation of the phenomenon:

In showing, which is also called the dramatic method or indirect presentation, the author simply presents the characters talking and acting and leaves the reader to infer the motives and dispositions that lie behind what they say and do . . . In telling, which is also called direct presentation, the narrator intervenes to comment directly on a character - singling out a trait for us to notice or making an evaluation of a character and his or her motives and disposition. $^{74}$

One can easily notice that the way Joseph of Arimathea is presented instantiates the telling technique. The noun $\mu \alpha \theta \eta \tau \eta \dot{s}$ ("disciple") and the participium coniunctum ڤ̋v ("being"), read here as a causative form; i.e., serving as the adverbial of cause (reason), hence allows for it to be translated as "because he was," 75 sheds light on the motivation of the man's actions: he went to Pilate and asked to be given the body of Jesus, because he was His disciple. That is why he wanted to take care of his deceased Master, giving Him a rightful funeral. Had he been a complete stranger, it would have proven rather taxing to commit to the undertaking, particularly in such unfavourable circumstances (threat), as well as in the context of the fact that at Golgotha there were Jesus's relatives, much more obligated to entomb the Crucified.

Now, in the case of Nicodemus, we are dealing with an instance of showing. The account of the funeral, in which we see him bring a specified amount (see below) of myrrh and aloe, and join efforts with Joseph, a secret disciple of Jesus, as well as other details scattered throughout the narrative point to Nicodemus's being a disciple. Despite the fact that the term $\mu \alpha \theta \eta \tau$ in s was not used with reference to him, we can safely say that — just like Joseph of Arimathea-Nicodemus is a true disciple of Jesus, who at last found the courage to present his identity to the world. Michael R. Whitenton wrote about it thus: "[a] number of factors suggest that

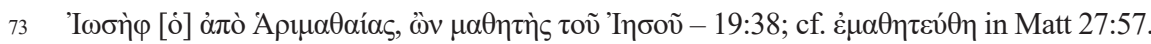

74 Resseguie, Strange Gospel, 126-127.

75 Cf. J. Piscator, Commentarii in omnes libros Novi Testamenti (Herbornae Nassoviorum [s.n.] 1638)

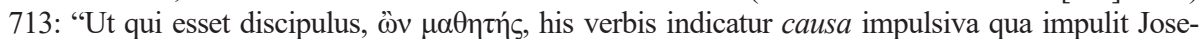
phum ut corpus Jesu a Pilato peteret" (emphasis added). The commentary to this philological entity was provided, i.a. by: Wallace, Grammar, 631, and Piwowar, Sktadnia, 423 (§ 426). 
Nicodemus's final appearance serves as something of his coming out as a Johannine disciple and provides a model for certain audience members to follow." ${ }^{{ }^{76}}$

\subsection{Profession of Faith in Jesus, the Eternal Messiah-King}

Noteworthy are both the quality and the amount of the spices brought by Nicodemus ( $\dot{\alpha} \rho \omega ́ \mu \alpha \tau \alpha-19: 40)$. It was a mixture of myrrh and aloe, used (among other things) to "embalm" the body of a deceased person in order to cover up the stench of a decomposing corpse, and to stave off its decomposition for as long as possible. ${ }^{77}$ The mixture was not liquid (for instance, in the form of oil), but solid (at least on the occasion of a funeral). ${ }^{78}$ An interesting, and possibly not devoid of some significance, is the fact that both these substances-when mentioned in the Hebrew Old Testament as applied together-always appear in the context of people who are alive (cf. Ps 45:9; Song 4:14; Prov 7:17). Did the Evangelist mean to suggest that Jesus - even though he had died - is still alive (in his deity, in his human soul?), and direct his reader's thought towards His expected resurrection? What is more, in all the three unique passages of the Old Testament, myrrh and aloe appear in the context of love, which in the Gospel of John might be intended as emphasis placed on the affection and attachment motivating Nicodemus during the burial of Jesus.

Whereas the sheer amount of spices brought by Nicodemus proves rather astonishing: ca. a hundred pounds ( $\dot{\varsigma} \varsigma \lambda i \tau \rho \alpha \varsigma \dot{\varepsilon} \kappa \alpha \tau o ́ v)$, that is approximately

76 Whitenton, Configuring, 115.

77 Cf. T. Zahn, Das Evangelium des Johannes, 6 ed. (KNT 4; Leipzig: Deichert 1921) 672; M.-L. Rigato, Il Titolo della Croce di Gesù. Confronto tra i Vangeli e la Tavoletta-reliquia della Basilica Eleniana a Roma (TGST 100; Roma: Pontificia Università Gregoriana 2003) 215; A.J. Köstenberger, John (BECNT 4; Grand Rapids, MI: Baker Academic 2004) 555. A symbolic interpretation was put forth by Juan Mateos and Juan Barreto (El Evangelio de Juan. Analisis lingüistico y comentario exegetico, 2 ed. [Madrid: Cristiandad 1982] 835): "Los aromas son símbolo de vida. Con la enorme cantidad que lleva, se propone Nicodemo eliminar el hedor de la muerte (cf. 11:39)." Myrrh is a natural gum sap, extracted from the trunks and branches of some plants from the genus Commiphora, characterised by its strong fragrance and bitter taste. Meanwhile, aloe is an exotic plant with fleshy leaves of the lily family. These are perennials with fleshy, oftentimes spiky leaves. Some of their species are used in the production of a homonymous, aromatic juice of the characteristically bitter taste (Rigato, Titolo, 182). Greek names for both these herbs are "loanwords" from Hebrew.

78 Cf. J. Blinzler, Il processo di Gesù (trans. M.A. Colao Pellizzari) (BCR 6; Brescia: Paideia 1966) 363-364; R. Schnackenburg, Das Johannesevangelium. III. Kommentar zu Kap. 13-21 (HThKNT 4/3; Freiburg - Basel - Wien: Herder 1975) 349; H.N. Ridderbos, The Gospel of John. A Theological Commentary (Grand Rapids, MI: Eerdmans 1997) 627; Robinson, Priority, 283. 
$32.5 \mathrm{~kg} !^{79}$ There can be no doubt that the hyperbole was to highlight the magnanimity of Nicodemus's gesture. ${ }^{80}$

On one hand, it was the expression of his reverence of Jesus as Master. Possibly, the Evangelist was evoking the tradition echoed in rabbinic literature: late tractates of the Babylonian Talmud Avodah Zarah 11a and Semahot 8:6 mention an Onkelos / Aquila, who in honour of his master Gamaliel the Elder (dec. ca. 50 AD) burned seventy or eighty minas (i.e., ca. $35-40 \mathrm{~kg}$ ). Asked about the motive of his action, he answered, alluding to Jer 34:5: "Does Rabbi Gamaliel not deserve more veneration than a hundred futile kings?" 1

At the same time, it was a tribute to the deceased King, echoing the funerals of three kings - two biblical ones (Asa and Herod the Great), and Aristobulus III-during which great amounts of "aromatics" were used. 1) It should be noted that, of all descriptions of funerals in the LXX, the noun ó $\rho \omega \mu \alpha$ appears only in $2 \mathrm{Chr}$ 16:14, when speaking of the funeral of King Asa. ${ }^{82}$ 2) The interment of King Herod the Great is narrated by Josephus Flavius in his Bellum Iudaicum 1,670-671 and Antiquitates Iudaicae 17,196-199. The funerary procession, making its way from Jericho to Herodium (ca. $30 \mathrm{~km}$ ), as scrupulously represented by the historian, included as its key piece ca. five hundred slaves "carrying spic-

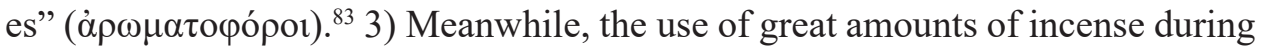

79 J.P. Louw - E.A Nida (eds.), Greek-English Lexicon of the New Testament based on Semantic Domains. I. Introduction and Domains, 3 ed. (New York: United Bible Societes 1989) § 86.4: " $\lambda i \tau_{\rho} \alpha$, a Roman pound, weighing about twelve ounces or about 325 grams". Also plausible seems the opinion that "100 litra . . . is obviously an exaggeration" (B. Lindars, The Gospel of John [NCBC; Grand Rapids, MI: Eerdmans - London: Marshall, Morgan \& Scott 1981] 592).

80 Wengst, Giovanni, 719, f.n. 262, referring to Pliny's Historia Naturalis, suggests that the cost of these spices fluctuated between 300 and 5000 denarii. Concurrently, he rejects as an overestimation Schnelle's proposal $(30,000)$, one that is also mentioned in the commentaries by, i.a., Craig S. Keener and Andrew T. Lincoln.

81 It is worth noting that the gesture towards the deceased master is more spontaneous and candid compared to official burial rituals of various dignitaries. Cf. M.-J. Lagrange, Évangile selon Saint Jean (EBib; Paris: Gabalda 1927) 503; D. Zlotnick - E.Y. Kutscher, The Tractate “Mourning”. Śémahot. Regulations Relating To Death, Burial, and Mourning. Translated from the Hebrew With Introduction and Notes by Dov Zlotnick. With Hebrew Text Vocalized by E.Y. Kutscher (YJS 17; New Haven, CT: Yale University Press 1966) 20; R.E. Brown, The Gospel According to John (XIII-XXI) (AB 29A; Garden City, NY: Doubleday 1970) 960.

822 Chr 16:14 (LXX) reports: "They buried him [Asa] in the tomb that he had hewn out for himself in the City of David. They laid him on a bier that had been filled with various kinds of spices (" $\varepsilon \lambda \eta \sigma \alpha \nu$

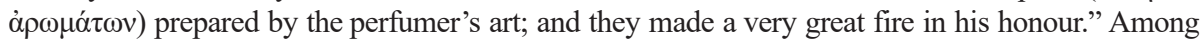
the exegetes who associate this detail with the entombment of Jesus we should list, i.a.: J.H. Bernard, A Critical and Exegetical Commentary on the Gospel According to St. John (ICC 63; Edinburgh: Clark 1928) II, 654; G.R. Beasley-Murray, John, 2 ed. (WBC 36; Nashville, TN: Word 1999) 359; L. Morris, Reflections on the Gospel of John. Crucified and Risen (John 17-21) (Grand Rapids, MI: Baker 1988) IV, 684.

83 Among the exegetes emphasising the similarity between numerous details in the description of the Passion of the Lord and between the funerals of Herod the Great and Jesus Christ we should name: C. a Lapide, Commentaria in Scripturam Sacram. XVI. In SS. Lucam et Joannem. Accurate 
the funeral of Aristobulus III, the last in the male line of the Hasmonean dynasty in $36 \mathrm{BC}$, is described by Josephus Flavius in Antiquitates Iudaicae 15,61 (“ $\pi \lambda \tilde{\eta} \theta 0 \varsigma \tau \tilde{\omega} v \theta v \mu 1 \alpha \mu \alpha ́ \tau \omega v ")$.

The volume of myrrh and aloe carried may at the same time manifest the notion of "the fullness of the messianic era." ${ }^{84}$ Lastly, Psalm 45, cited not long before, is not only a love song about the king's wedding, but also a messianic psalm (so explicitly in its Targumic version).

Closing the considerations of "myrrh and aloe," we should additionally note the absence of women during the preparations of Jesus's body for the funeral. These circumstances differ from those of the synoptics, which present solely the women deals with the "aromatics" and the entombment of Christ. ${ }^{85}$ In the Fourth Gospel, the embalmment of Jesus's body is performed - proleptically_by Mary in Bethany slightly earlier (12:1-8). ${ }^{86} \mathrm{John}$ structures his narrative in such a way as to "provide an opportunity" to honour the deceased Jesus most of all for the pair of His disciples, who had until then remained in hiding.

The joint effort by Joseph of Arimathea and Nicodemus manifested itself also in the "wrapping the body of Jesus with the spices in linen cloths," with the important remark that the procedure was performed "according to the burial custom of the Jews" (19:40). Maria-Luisa Rigato points out that the term ó $\theta$ ovíors (linen cloths), despite the use of plural, potentially problematic at first glance, does not necessarily contradict the other Gospels ${ }^{87}$ : instead, it may mean a single sheet of canvas, although folded at least in two. She evokes a phenomenon known in contemporary languages, that of nouns formally expressed in the plural, but meaning notions in the singular. These denote objects comprising at least two elements, such as scissors, glasses, trousers, pliers, etc. ${ }^{88}$ In such case, we are

recognovit ac notis illustravit Augustinus Crampon (Parisium: Vivés 1865) 622, f.n. 1; G.M. Burge, John. From Biblical Text ... to Contemporary Life (NIV Application Commentary 4; Grand Rapids, MI: Zondervan 2000) 536, 541-542; F.F. Bruce, The Gospel of John. Introduction, Exposition and Notes (Grand Rapids, MI: Eerdmans 1983) 382, f.n. 45.

84 H. Thyen, Das Johannesevangelium (HNT 6; Tübingen: Mohr Siebeck 2005) 754 speaks of "messianische Fülle," while referring to R.E. Brown and Ulrich Wilckens. Cf. also J. Murphy-O'Connor, "The Descent from the Cross and the Burial of Jesus (John 19:31-42)," RB 118 (2011) 545. Suffice it to mention the six stone jars of water / wine, each holding two or three firkins, meaning between 480 and 720 litres in total if we take the "measure" to be ca. 40 litres (2:6), the amount of the broken bread that fed the multitudes (6:1-13), or 153 great fish of the miraculous draft (21:11).

85 Cf. $\alpha \rho \omega ́ \mu \alpha \tau \alpha$ in Mark 16:1 and Luke 23:55-24:1; cf. Mt 28:1.

86 Auwers, "Nuit," 495, f.n. 64: "litra: uniquement en 12,3 et 19,39; entaphiasmos (12:7) et entaphiazein (19:40); la grandequalité de parfum (12:3) et l'abondance des aromates (19:39)."

87 The synoptic Gospels, when speaking of $\sigma \mathrm{v} \delta \omega \dot{ } v$, a thin cloth typically of linen, use forms of the singular (cf. Matt 27:59; Mark 15:46; Luke 23:53).

88 Cf. Rigato, Titolo, 198-213. 
dealing with the plural of generalisation or category, ${ }^{89}$ related to the rhetorical figure of syllepsis. ${ }^{90}$

The author - on the basis of data drawn from extra-biblical literature (Mishnah, Aristaeus, Philo of Alexandria, Josephus Flavius and others) - cites an estimate value of such a piece of cloth (between two and five thousand drachmae). ${ }^{91}$ Above all else, however, the Italian exegete emphasises that "neither in the Bible, nor in the works by Philo of Alexandria . . . nor in those by Joseph Flavius, do we find any indications of the custom of preparing the grave [and the funeral]

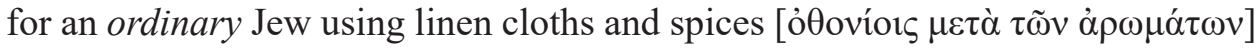
... The tradition that St John alludes to may have concerned solely the king's burial." ${ }^{2}$ The indication of it being "the burial custom of the Jews" (19:40) is, therefore, not (only) intended to differentiate it from, say, Egyptian embalming or Roman cremation of corpses. ${ }^{93}$ Thanks to the emphasis placed on the use of high-quality linen and of great amounts of myrrh and aloe (beside other data presented in 19:38-42), it serves to highlight the truth of the kingly status of Jesus. ${ }^{94}$

89 Cf. M. Zerwick, Biblical Greek Illustratedby Examples (SPIB 114; Roma: PIB 2001) § 7; Blass Debrunner - Rehkopf, Grammatik, 116-117 (§ 1412).

90 Cignelli - Pierri, Sintassi, § 11,1: "un tropo ... sillèssi, per cui parliamo di uno solo al plurale.” Urban von Wahlde $(J o h n, 831)$ shares that opinion: "the plural of the word may not necessarily indicate more than one piece but rather refer to the size of the material."

91 It should be pointed out that the value of ỏ $\theta$ óvıov in all likelihood surpassed that of $\sigma \mathrm{v} \delta \omega \mathrm{v}$, considering that "[i]t is not justified ... to claim that sindōn was of such quality that readers would have to recognize the burial as honorable" (Brown, Death, 1244, f.n. 4). Joseph Knabenbauer, on the other hand, commenting on 19:40, describes the cloths (ỏ $\theta$ óvı $\alpha$ ) as (very) valuable: "llintea illa fuisse pretiosa" (Commentarius in quatuor S. Evangelia Domini N. Iesu Christi. IV. Evangelium secundum Ioannem [CSS 4; Parisiis: Lethielleux 1906] 569). The information seems particularly surprising in light of the fact that convicts who died on the cross were thrown into a common, dishonourable grave: "Jewish people may have usually buried condemned criminals in a common grave reserved for that purpose ... a purposely shameful burial" (Keener, John, 1157).

92 Rigato, Titolo, 178-179.

93 Cf. C.K. Barrett, The Gospel According to St. John. An Introduction with Commentary and Notes on the Greek Text (London: SPCK 1955) 465; J. Zumstein, L'évangile selon saint Jean (13-21) (CNT 4b; Genève: Labor et Fides 2007) 263, f.n. 8.

94 Cf. R. Bultmann, Das Evangelium des Johannes, 16 ed. (Götingen: Vandenhoeck \& Ruprecht 1959) 527, f.n. 11; R. Kysar, John (ACNT 4; Minneapolis, MN: Augsburg 1986) 293-294; T.L. Brodie, The Gospel According to John. A Literary and Theological Commentary (New York - Oxford: Oxford University Press 1993) 559; P. Dschulnigg, Jesus begegnen. Personen und ihre Bedeutungim Johannesevangelium (Theologie 30; Münster - Hamburg: LIT 2000) 119; J.A. Draper, "What Did Isaiah See? Angelic Theophany in the Tomb in John 20:11-18," Neot 36 (2002) 69; Ch. Dietzfelbinger, Das Evangelium nach Johannes, 2 ed. (Zürich: Theologischer Vorlag 2004) II, 315; W. Hendriksen, Exposition of the Gospel According to John. Two Volumes Complete in One, reprint (NTC 4; Grand Rapids, MI: Baker Academic 2007) 445; H. Witczyk, "Historia w ewangelicznych świadectwach o Męce i Śmierci Jezusa," Jezus i Ewangelie w ogniu dyskusji. Od H. Reimarusa do T. Polaka (eds. J. Kudasiewicz - H. Witczyk) (BiVeVi 2; Kielce: Instytut Teologii Biblijnej "Verbum" 2011) 280. The above interpretation was rejected by Jürgen Zangenberg ("«Buried according to the Customs of the Jews». John 19:40 in Its Material and Literary Context," The Death of Jesus in the Fourth Gospel [ed. G. van Belle] [BEThL 200; Leuven - Paris - Dudley, MA: Leuven Uni- 
There is another important detail related to the above issue: Jesus was buried in a grave that was situated in a garden (19:41-42). Although the term $\kappa \tilde{\eta} \pi \mathrm{s} \varsigma$ (garden) appeared already in John 18 to describe the place where Jesus was captured (to the east of ancient Jerusalem), in the case of the funeral it points to a different "garden" (situated west of the Holy City). By serving to establish a compositional device (inclusio) encompassing the entire Passion of the Lord (18:1-19:42), the word conveys a similar motif: in both cases we are dealing with the place where Christ triumphed over "the enemy" "95; the Evangelist might also be hinting at the notion of "the garden of Eden."

In the case of joint undertaking by Joseph of Arimathea and Nicodemus, we are more interested, however, in pursuing the theme of the royal status of the burial they prepared for Jesus. As it turns out, the noun $\kappa \tilde{\eta} \pi \circ \varsigma$, used 26 times in the Septuagint, on four occasions pertains to gardens in which the tombs of the kings were situated. Moreover, the remaining 22 instances of that term being used in the Greek Old Testament are in no way related to anybody's burial place. Hence, the only "tombs in a garden" directly indicated in LXX are the tombs of kings. Specifically, these are: Manasseh, Amon, and someone as distinguished as their forebear - King David..$^{97}$ On the basis of a piece of information provided in Acts 2:29, we may infer that people living at the time of composition of the New Testament were quite familiar with David's tomb. Hence, the association between the motif of "a tomb in a garden" and the "kingly status" of the person buried therein should not cause any trouble to the readers of the Gospel.

Furthermore, it is perfectly conceivable that the argument is corroborated by an additional, implicit premise. In the fragments where the Old Testament recounts the deaths of subsequent kings of Judah (from David to Ahaz), a consistent, almost invariant formula is used: "slept with his ancestors and was buried in

versity Press - Peeters 2007] 887-888), who claims that the burial of Jesus was not of the royal kind but rather that it resembled "«civic» burials of wealthy upper class families," whereas the mention of "the burial custom of the Jews" is only aimed to further underscore that Jesus belonged to the Jewish nation continuously, without any interruptions also after his demise: "a Jew for all times" (ibidem, 891-892).

95 The fall to the ground of the mob sent from the chief priests in 18:6 is "mirrored" in the resurrection of Christ in John 20: both passages present the triumph over the (representatives of) forces of darkness. Cf. A. Westcott, The Gospel According to St John. The Greek Text with Introduction and Notes. By late Brooke Foss Westcott (ThC 4; Grand Rapids, MI: Baker Book House 1980) II, 324: "кп̃ $\pi$ os, Comp. XVIII. 1. The scene of the betrayal and the scene of the triumphant rest answer one to the other."

96 Cf. Renz, "Nicodemus," 276-277; M. Rosik, "Discovering the Secrets of God's Gardens. Resurrection as New Creation (Gen 2:4b-3:24; John 20:1-18)," LASBF 58 (2008) 81-98; Witczyk, "Historia," 280-281 and many others (e.g. Benedictus Aretius, Johannes Piscator, Frédéric Manns, John A.T. Robinson, Rudolf Schnackenburg, Jacek Oniszczuk, Ignace de la Potterie, Ruben Zimmermann, John N. Suggit).

97 Cf. 2 Kgs 21:18.26; Neh 3:16 (LXX). 
the City of David." ${ }^{98}$ Now, when it speaks of the burials of the subsequent kings of Judah (from Hezekiah to Jehoiachin), admittedly the reference to the City of David is omitted, but there is a mention that they "slept with [their] ancestors" and occasionally of a burial in the garden. ${ }^{99}$ It is possible, then, that all these kings, regardless of whether or not the word $\kappa \tilde{\eta} \pi \circ \varsigma$ was actually used, were buried in a tomb situated in the royal gardens. ${ }^{100}$ Having made such an assumption, no longer is it difficult to demonstrate the royal character of Jesus's burial. ${ }^{101}$

\subsection{Nicodemus: Hero or Villain?}

\subsubsection{Negative Appraisal}

Bearing in mind the severe criticism expressed by the exegetes Nicodemus's attitude until that point, one can easily guess that his third appearance in the Gospel was met with negative opinions. For many authors, Nicodemus made no progress in faith and until the very end remains an "ambiguous" figure. ${ }^{102}$ The manner that

98 David (1 Kgs 2:10); Salomon (1 Kgs 11:43); Rehoboam (1 Kgs 14:31); Abijah (1 Kgs 15:8), Asa (1 Kgs 15:24); Jehoshaphat (1 Kgs 22:51); Jehoram (2 Kgs 8:24); Ahaziah (2 Kgs 9:28); Jehoash (2 Kgs 12:22); Amaziah (2 Kgs 14:20); Azariah (2 Kgs 15:7); Jotham (2 Kgs 15:38); Ahaz (2 Kgs 16:20).

99 Hezekiah (2 Kgs 20:21); Manasseh (2 Kgs 21:18); Amon (2 Kgs 21:26); Jehoiachin (2 Kgs 24:6).

100 A. Kubiś, "Zechariah 6:12-13 as the Referent of $\gamma \rho \alpha \varphi \eta$ in John 2:22 and 20:9. A Contribution to Johannine Temple-Christology," BibAn 2 (2012) 183-184, f.n. 71: "till Ahaz the kings of Judah were buried within the City of David, in the royal palace.... Hezekiah, the perpetrator of the cultic reform (2 Kgs 18:4.22; $2 \mathrm{Chr} 29-31$ ), was supposedly the first one to be buried outside the city, in king's garden (the garden of Uzzah), which was planted by him on the slopes of the Kidron Valley near the city walls at the southeast of the City of David. The choice of the new royal burial place outside the city was motivated by a sense of the impurity attached to graves (see again Ezek 43:7-9). It cannot however be excluded that there were two royal gardens: one inside the City of David and one outside, in the Kidron Valley. Both of them might be connected with the royal palaces" (emphasis added).

101 There are two more instances worth adding to the number of royal "burials in a garden," directly presented in the Scripture. The first receives a mention from Josephus Flavius in his Antiquitates I $u$ -

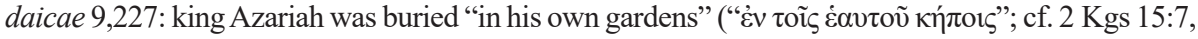
where that piece of information is missing). The other comes from Luciani's version of the Septuagint $\left(\mathrm{LXX}^{\mathrm{L}}\right)$, where in $2 \mathrm{Kgs}$ 24:6 we learn that Jehoiachin "was buried in the Garden of Uzzah with

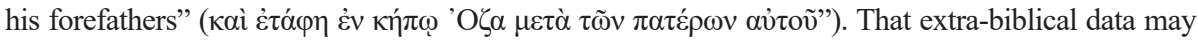
serve as corroboration of the above-presented hypothesis regarding the burial of many kings of Judah in gardens.

102 Cf. Lincoln, John, 485; M. Pamment, "Focus in the Fourth Gospel," ExpTim 97 (1986) 73; Bassler, "Mixed," 646; Munro, "Pharisee," 727; Donaldson, "Nicodemus," 124; R.F. Collins, These Things Have Been Written. Studies on the Fourth Gospel (LThPM 2; Louvain: Peeters - Grand Rapids, MI: Eerdmans 1990) 14-15; J.L. Staley, "Subversive Narrator/Victimized Reader: A Reader Response Assessment of a Text-Critical Problem, John 18.12-24," JSNT 51 (1993) 86; C.L. Blomberg, "The Globalization of Biblical Interpretation: A Test Case - John 3-4," BBR 5 (1995) 7; C.M. Con- 
he had performed the funeral of Jesus has also been the subject of reproval, particularly with the accompanying suggestion that he did not believe in the (prompt) resurrection of Christ. ${ }^{103}$ Unfavourable is also the interpretation of his absence at the crucifixion, when Jesus established the family of God (19:25-27). ${ }^{104}$ Such is also the opinion of his absence at the scene of the resurrection. ${ }^{105}$ According to Marchadour, "the constant recalling of his nocturnal visit might mean that the Nicodemus's relationship with Jesus had not undergone any transformation after that notable night." ${ }^{106}$ Moreover, the fact that he joined efforts with Joseph of Arimathea, a disciple "though a secret one" (19:38) suggests that Nicodemus, too, did not find the courage to publicly profess his faith in Jesus. ${ }^{107}$

In answer to the above, we could point out that each character has a specific role to play and does not necessarily have to be present in every scene of the Gospel. ${ }^{108}$ After all, in the account of the events occurring after the resurrection, one cannot expect to catch sight (as explicitly mentioned) of such important positive figures as the Woman of Samaria (4:4-42), the royal official (4:46-54), the blind from birth (John 9), Martha, Mary, and Lazarus (11:1-44), or even the mother of Jesus $(2: 1-12 ; 19: 25-27)$. What is more, His disciples, "locked for fear of the Jews" (20:19.26), behave in a manner not worth imitating, as they keep on hiding even after they have met the risen Jesus and have been granted the Holy

way, Men and Women in the Fourth Gospel. Gender and Johannine Characterization (SBLDS 167; Atlanta, GA: SBL 1999) 103; Sevrin, "Nicodemus," 368-369: "for the third time, there is no clear indication that he has changed, nor that he comes out of the night in 19:39 . . Nicodemus does not recognize Jesus as the Messiah. He is not a believer ... [H]e remains unaccomplished . . . ambiguous and marginal ... in-between ... neither on the side of those who reject nor on the side of those who believe"; S.E. Hylen, Imperfect Believers. Ambiguous Characters in the Gospel of John (Louisville, KY: Westminster John Knox 2009) 23, 36-37; R. Hakola, "The Burden of Ambiguity: Nicodemusand the Social Identity of the Johannine Christians," NTS 55 (2009) 438-455; Zangenberg, "Buried," 877-878; Hunt, "Nicodemus," 205: "Nicodemus remains at most a private disciple of Jesus, one afraid to confess his stand publicly"; Bennema, "Nicodemus," 155-158: "Nicodemus has made progress since John 3 and 7. But ... [he] shows a curious mix of boldness and fear, in both John 7 and 19 ... [He] ultimately remains who he is - sympathetic but ambiguous ... John implicitly gives a negative evaluation of Nicodemus's ambiguity - to stay in the twilight zone is not acceptable . . [ [N]o ... confession or discipleship" (emphasis added).

103 Cf. Meeks, "Man," 149; R.A. Culpepper, Anatomy of the Fourth Gospel. A Study in Literary Design (Philadelphia, PA: Fortress 1983) 136; D.D. Sylva, "Nicodemus and his Spices (John 19:39)," NTS 34 (1988) 148; M. Davies, Rhetoric and Reference in the Fourth Gospel (JSNTSup 69; Sheffield: JSOT Press 1992) 337; L.W. Countryman, The Mystical Way in the Fourth Gospel. Crossing over into God (Valley Forge, PA: Trinity Press International 1994) 132; J.P. Heil, Blood and Water. The Death and Resurrection of Jesus in John 18-21 (CBQMS 27; Washington, DC: Catholic Bible Association of America 1995) 115; de Jonge, "Nicodemus," 343.

104 Cf. Marchadour, Personaggi, 73.

105 Cf. Marchadour, Personaggi, 73; Wengst, Giovanni, 717; Metzner, Prominenten, 338-339.

106 Marchadour, Personaggi, 73.

107 Cf. Culpepper, "Nicodemus," 258-259; Bennema, "Nicodemus," 154.

108 Cf. Schnackenburg, Johannesevangelium, III, 348-349. 
Spirit (20:22). ${ }^{109}$ Now, anyone suggesting that executing the burial was a sign of their disbelief in the resurrection (of Jesus), ${ }^{110}$ ought to acknowledge that the Fourth Evangelist in his account of the Passion of the Lord, as opposed to some of the synoptics (Matt 27:60, Mark 15:46), does not speak of the stone rolled at the entrance of the tomb. ${ }^{111}$ This may well be a narrative indication pointing to the open-mindedness of Joseph and Nicodemus regarding the possibility of Jesus's resurrection. ${ }^{112}$ Furthermore, the repeated reference to Nicodemus's coming at night - "the night" conceived as a symbol of fear and disbelief - may still be

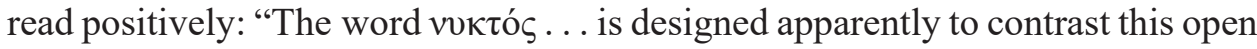
act of reverence to Christ, done before the day had closed, with the secrecy of his first visit." 113 This contrast is underscored i.a. by "[t]he emphatic positioning of

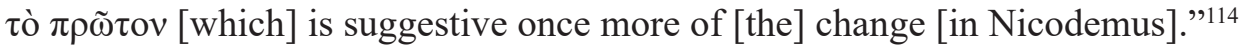

\subsubsection{Positive Appraisal}

By appraising both men most positively, we would like to emphasise the fact that Nicodemus and Joseph of Arimathea perform together a deed they were never obligated to before: it was the natural duty of the mother of Jesus and His disciples, accompanied by the women present at the crucifixion, to bury their Son / Master. Moreover, in order to abide by the precept of Deut 21:22-23, they did not have to hold such a costly and solemn burial. Further still, in light of Num 9:10-11, both members of the Sanhedrin due to coming in contact with a corpse have incurred ritual impurity, thus losing the right to eat the Passover that evening (cf. 18:28): in such case, the Law prescribed postponing the cele-

109 This marks the contrast between them and the attitude displayed by Joseph of Arimathea and Nicodemus, who act overtly, and that even before Jesus has risen from the dead.

110 These type of potential objection was confronted by J. Davies, Death, Burial and Rebirth in the Religions of Antiquity (RFCC; London - New York: Routledge 1999) 112: "The general expectation of an afterlife is most clearly stated in Sanhedrin in both the Mishnah and in the Babylonian Talmud ... [T] he comforting idea of an afterlife must have persisted as part of the funerary ethos of at least some Jews as they contemplated life and death."

111 Brown, Death, 1267-1268: "although John knows of a stone before the entrance to the tomb (20:1), he does not have Joseph and Nicodemus close or seal the tomb . . . John transformed the crucifixion into the triumph of Jesus; so also he has transformed the burial into a triumph"; Westcott, John, 324: "it is implied that the sepulchre in which the Lord was laid was not chosen as His final resting-place"; Brodie, John, 559: "the garden and the brand new tomb . . . suggest a place which, instead of being a dead end, is in some way a beginning."

112 B. Aretius, In Novum Testamentum Domini nostri Iesu Christi Commentarii Doctissimi Benedicti Aretii Bernesis Theologi praestantissimi, facili per spicuaque methodo conscripti (Genevae: Chouët 1618) 1032; Piscator, Commentarii, 715; M. Sabbe, "The Johannine Account of the Death of Jesus and its Synoptic Parallels (John 19:16b-42)," ETL 70 (1994) 54-55; Auwers, "Nuit," 494, f.n. 58.

113 Westcott, John, 323.

114 Whitenton, Configuring, 109. 
bration of the Feast by a month. ${ }^{115}$ To quote Vignolo: "now the only thing that matters to them is the Passover of Jesus." 116 If we add the reason behind their remaining in concealment until that moment, that is the apprehension of being rejected from the Synagogue (or, what seems more plausible: of losing their good name in the Council of Elders and the subsequent persecution), ${ }^{117}$ and taking into consideration the significance of the above-discussed respective elements of the funeral, it is easy to see that both these disciples - until that moment in hiding - have stepped out of the shadows and publicly ${ }^{118}$ paid tribute to Jesus as their Master and King. We can observe, then, that Nicodemus's attitude has change compared to that of John 3: the final episode that he appears in shows him definitely break with the darkness of the "night" and act in the light of a setting, but still present sun. ${ }^{119}$ However, it is not only the "darkness of fear" that has been overcome. Also the "darkness of disbelief" is losing its grip on him during the burial prepared for Jesus, for it provided an opportunity to testify to his faith in all attributes of Jesus's identity, associated with the respective elements of Nicodemus's gestures.

Unquestionable progress has occurred in relation to John 7 as well. In his second scene, Nicodemus very courageously stood up for Jesus and in defence of the precepts of the Law. For the Sanhedrin, Jesus was an usurper claiming the appellation of Messiah and Prophet, attributed to him by some of the Jews who listened to Him (7:26-27.40-42). For Nicodemus, it was more than just a hypothetical pretender to the title of God's Anointed One. To the extent that the circumstances allowed, that is faced with the inability of his aggressive colleagues unable to even hear his rational argumentation, Nicodemus proved the only one to speak out for Jesus. At that juncture, however, he only ventured to that before a very specific group of listeners: chief priests, Pharisees, and the temple police (7:45). In 19:38-42, the effort undertaken together with Joseph of Arimathea is performed in front of everyone present in the vicinity of Calvary or looking towards it from (the walls of) Jerusalem (cf. 19:20). The burial of Jesus was therefore for him an opportunity to reveal himself before "the whole world," including Christ's Apostles and the women who followed him, who-perhaps slightly confounded - became aware that the number of Jesus' disciples includes these two members of the Sanhedrin. It is worth noting that in this third scene,

115 Cf. Brown, Death, 1216; von Wahlde, John, 830-831; Burge, John, 535; Mateos - Barreto, Juan, 835; Manns, Ecce, 327.

116 Vignolo, Personaggi, 118. In a similar vein: Grasso, Giovanni, 747 and F.D. Bruner, The Gospel of John. Commentary (Grand Rapids, MI - Cambridge: Eerdmans 2012) 1135.

117 Cf. Burge, John, 547; J.-A.A. Brant, John (Grand Rapids, MI: Baker Academic 2011) 255.

118 Cf. Moloney, John, 510; Morris, Reflections, 682; Lindars, John, 592; Dschulnigg, Jesus begegnen, 120; C. Grappe, "Les nuits de Nicodème (John 3:1-21; 19,39). À la lumière de la symbolique baptismale et pascale du quatrième évangile," RHPR 87 (2007) 273.

119 Cf. Brodie, John, 559; Bauckham, "Nicodemus," 31; Whitenton, Configuring, 116. 
the Evangelist does not present Nicodemus as "a Pharisee" (3:1), nor "one of them" (7:50); both him and Joseph of Arimathea have now become true disciples of Jesus Christ.

\subsection{The Exaltation of Jesus as the Moment of Birth and Emergence of Disciples}

A psychological look at the events unfolding at Calvary leads one to an additional inference. Nicodemus's natural reaction to Jesus's death - seemingly Christ's utter failure - which he probably witnessed (observing it from afar, cf. 19:20) should be that of quiet withdrawal; feeling slightly ashamed of himself and at the same time experiencing a possible "satisfaction" at least from the fact that his fascination with Jesus remained secret, known to no-one. He should be saying to himself, "What have I done? I wasted so much time and energy! I grew to be interested in that Man, I was moved by the signs he made, fascinated with the words that he uttered... But he has obviously lost now, and without Him, all hope is lost." Instead, Nicodemus at that very moment, in the hour of the crossand not because of the miracles before - he decides to manifest to everyone his adherence to Jesus, and, disregarding the consequences, is involved in public organisation of His burial.

It accords well with the Johannine idea of "the glory of the cross" as an instrument not of ignominy, but rather of "exaltation." The Fourth Evangelist, as opposed to synoptics, who only report the thrice foretold torment of the Son of Man, ${ }^{120}$ announces tree times also that he would be "lifted up" $(3: 14 ; 8: 28$; 12:32-34). For the first time, these words are uttered during Jesus's conversation with Nicodemus. Meanwhile, the final foretelling leaves no more doubts as to the significance of the verb vifó $\omega$ : it means the death of Jesus (12:33), involving the actual "lifting" of His body (12:32.34) and that - considering the frequent double entendres of John's terminology - concurrently indicates his "lifting up / glorification." 121 Dying, Jesus "will draw all people to [himself]" (12:32-33).

120 Cf. Matt 16:21; 17:22; 20:17; Mark 8:31; 9:30; 10:33-34; Luke 9:22.44; 18:31-33.

121 Cf. K. Tsuchido, "The Composition of the Nicodemus-Episode, John ii 23 - iii 21," AJBI 1 (1975) 95-96; J. Blank, Krisis. Untersuchungen zur johanneischen Christologie und Eschatologie (Freiburg im Breisgau: Lambertus 1964) 269, f.n. 12: "the hour of the $\delta o \xi \alpha \sigma \theta \tilde{\eta} v \alpha l$ is the hour of the passion, but the reverse: the hour of the passion is already the hour of the $\delta$ o $\xi \alpha \sigma \theta \tilde{\eta} v \alpha \imath$ "; M.-A. Chevallier, "La fondation de 'l'Église' dans le quatrième Évangile: Jn 19,25-30," ETR 58 (1983) 351-352; J. Ashton, Understanding the Fourth Gospel, 2 ed. (New York: Oxford University Press 2007) 469-470: "So «lifting up» and «glorification» are alternative and complementary ways of speaking of the same event"; T.G. Brown, Spirit in the Writings of John. Johannine Pneumatology in Social-scientific Perspective (JSNTSup 253; London-New York: Clark 2003) 99; M.C. de Boer, "Johannine History and 
The prophesy concerns not only the bringing together of the newly-established family of God at the foot of the cross (19:25-27), but also the decision taken by Nicodemus and Joseph of Arimathea to step out of hiding, taking Jesus's body from the cross, wrapping Him in linen cloths, etc. Cross turned out to be a sign

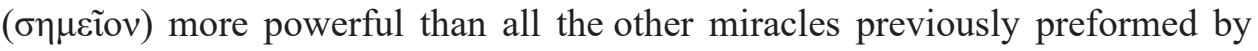
Jesus $^{122}$ : this until then symbol of cruel and shameful suffering (cf. 1 Cor 1:23; Gal 5:11) shone with the might and the resplendent glory of Jesus (cf. 1 Cor 1:24). As a result, also the Cross itself became a sign of glory, that manifested itself in Nicodemus's deed. His triumph over his own fear and appearing from the darkness occurred in the hour of Jesus's being lifted on the cross, from the elevation of which Master drew all his disciples - also the secret ones - to himself. ${ }^{123}$ It is also through Nicodemus that the Crucified's glory can be seen. ${ }^{124}$

Nicodemus's gesture was more than an underscoring of the truth of gloria Crucis. His cooperation with Joseph constitutes a locus theologicus for the revelation, through which Christs acquaints us with other aspects of his identity. ${ }^{125}$ Jesus, though he does not display any signs of life, continues to reveal Himself, for owing to the acts of his both disciples — as if in a reflection of light — he still appears as the Master and Messiah-King.

Johannine Theology: The Death of Jesus as the Exaltation and the Glorification of the Son of Man," The Death of Jesus in the Fourth Gospel (ed. G. Van Belle) (BEThL 200; Leuven - Paris - Dudley, MA: Leuven University Press - Peeters 2007) 293-327; Kubiś, "Zechariah,” 170: “The Johannine... Jesus' crucifixion is the hour of his glorification."

C.H. Dodd, The Interpretation of the Fourth Gospel (Cambridge: Cambridge University Press 1968) 438-439: "Guided, than, by the pointers which the evangelist has provided, we find in the story of

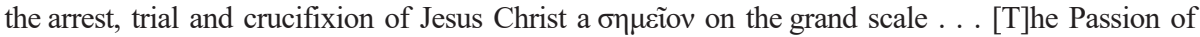

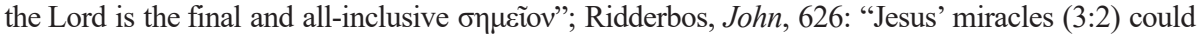
not bring Nicodemus to openly join Jesus' disciples, but Jesus' death can”; Hendriksen, John, 442: "But now, as a fruit of Christ's atoning death and love for him, this man has suddenly become very courageous."

123 Burge, John, 547: "Jesus has been lifted up on the cross, Joseph and Nicodemus are drawn (cf. 12:32)"; Kysar, John, 293: "The author may be implying that the crucifixion brought these «closet believers» to public confession"; Grappe, "Nuits," 273; Dschulnigg, "Nikodemus," 264; C.R. Koester, "Theological Complexity and the Characterization of Nicodemus in the Gospel of John," Characters and Characterization in the Gospel of John (ed. C.W. Skinner) (London: Clark 2013) 180.

124 Schnackenburg, Johannesevangelium, III, 349: "das Begräbnis Jesu wie dann auch sein Grab sollen die Herlichkeit Jesu enthüllen, die sichim Tun jener beiden Männer widerspiegelt."

125 The notion of locus theologicus is alluded to by Gail R. O'Day (Revelation in the Fourth Gospel. Narrative Mode and Theological Claim [Philadelphia, PA: Fortress Press 1986] 94, 96), when she writes of "the locus of revelation," suggesting that the reader of the Gospel learns about the revelation of Jesus (also) by analysing the attitudes of the disciples (and particularly the misunderstandings they are liable to). 


\section{Conclusion}

John's Nicodemus, whose homonymous prototype might have been Naqdîmôn bēn Gûrion (known from rabbinic literature), appears only in the Fourth Gospel. This Pharisee, Jewish dignitary, is presented in three episodes, which require to be read together as a single whole (cf. 3:2; 7:50; 19:39).

His night-time encounter with Jesus $(3: 1-21)$ persuades most scholars to express their more or less negative appraisal of him. Even though he arrives to Jesus of his own accord and greets Him with words full of reverence, even bearing marks of a profession of faith in Jesus's divine origin $(2: 23 ; 3 ; 2)$, he ultimately deserves criticism. Negatively perceived is his fear of the meeting with the intriguing Rabbi being exposed before the others and his misunderstanding of Jesus's words of rebirth as the condition for entering the Kingdom of Heaven. Reading the plural of the verb "we know" (oî $\delta \alpha \mu \varepsilon v)$ in 3:2 as pluralis modestiae, we interpret it as a symptom of Nicodemus's apprehension and insecurity also towards Jesus. The pericope ends in a rather surprising manner. It turns out that Nicodemus - a teacher of Israel (3:10) - does not react to the subsequent words of his interlocutor and in fact disappears from the scene. The dialogue with Jesus has transformed into His monologue and as a result of that their colloquy ended in suspension.

Also the second episode in the Gospel where we find Nicodemus (7:45-53) inspired numerous exegetes to assess the figure of our interest negatively. However, one should acknowledge certain details in the intervention performed by Nicodemus that scholars pay little attention to. First of all, a feature worth underscoring is the denotation, that is the fact of Nicodemus's deft (both in terms of its meaning and form) reference to the precepts of the Law. But the connotation, i.e. the context of the words spoken by Nicodemus, deserves even more attention. The man witnessed the harsh reprimand given by the chief priests and the Pharisees to the temple police, amazed at the things said by Jesus (7:45-49). Hence, he must have been entirely certain that he, too, would be chided. He did not hesitate, however, to stand up for Jesus. Aware of the fact that it is impossible to dialogue with an aggressive interlocutor, he left their fierce words unanswered. Convinced of being right, he expressed the truth, whereas the decision whether to accept or reject it was at the hands of his colleagues.

Admittedly, in this second scene Nicodemus did not explicitly state who Jesus was for him. Still, he took to defend the Man considered by the mob to be a Prophet and the Messiah (7:40-41a). Had his demand to interrogate Jesus been accepted - and it sadly was not-it would have been ascertained that Jesus is indeed God's Anointed One. Nevertheless, the reluctance displayed by the chief priests and the Pharisees challenged with the rhetorical question posed by Nicodemus can 
hardly be surprising. He spoke his words before those who for a long time already had intended to kill Jesus $(5: 18 ; 7: 1.19-20.25)$ and had started to threaten the crowd with the banishment from the synagogue $(9: 22 ; 12: 42 ; 16: 2)$. Even though his intervention does not yet posses the openly public character, that moment already marks Nicodemus's step forward with regard to his timid, fear-stricken nocturnal arrival to Jesus (3:1-2). And considering the fact that the Feast of the Tabernacles (John 7) are firmly founded on the symbolism of light, the Evangelist seems to be suggesting that Nicodemus starts to slowly emerge from the darkness of his fear and disbelieve and move towards the light (cf. $3: 21 ; 8: 12$ ).

In a definitive manner, Nicodemus manifested to the world his adherence to Jesus in the final scene of the Lord's Passion (19:38-42). Together with Joseph of Arimathea (still before the sunset), he gave Jesus a royal burial. ${ }^{126}$ By that deed, he paid a tribute to Him also as the Messiah, a Prophet, and his Master. It has to be underscored, however, that this gesture of disciple's love was ultimately motivated by the "exaltation of the Son of Man." No other sign performed by Jesus proved powerful enough to enable Nicodemus to fully adhere to Jesus and courageously manifest that before everyone. The decisive moment came with Christ's Death on the Cross that - as the ultimate sign ( $\sigma \eta \mu \varepsilon i ̃ o v)$ in the Fourth Gospelby the might of its glory was able to bring the disciple from the darkness of fear ("night") and lead him to the light of faith, i.e. a living relationship with Jesus. At that point, it became apparent to everyone, meaning besides coincidental observers of the crucifixion (19:20), also for the Apostles of Christ, as well as for the leaders of the people, posing a threat for the followers of Jesus $(9: 22 ; 12: 42$; 16:2). The fear paralysing Nicodemus (3:2) and Joseph of Arimathea (19:38) before, was definitively alleviated. Thus, the expected hostile reaction to their attitude from the Sanhedrin did not matter much for them anymore.

These two new disciples of Christ came to be a locus theologicus for the revelation of Jesus. Their Master, though deceased, and hence unable to utter words and perform miracles, never stopped to manifest Himself. In Nicodemus and in Joseph of Arimathea - as if in a reflection of light — Jesus continued to show himself to the world as the Prophet, Messiah, and King, as well as a Master worthy of his disciples' love.

Nicodemus is a person through whom the glory of Jesus's Cross became manifest. Concurrently, however, the crucifixion itself proved to be an opportunity for the emergence of other disciples of Jesus. Besides the just-constituted God's family present at Golgotha (19:25-27), also Joseph and Nicodemus had been drawn by the Crucified (12:32) to join familia Dei. They experienced in their hearts the "rebirth" for the Kingdom of God (3:3-8).

126 Cf. the amount and quality of the aromatics, linen cloths, and the tomb in a garden. 
Drawing all the above inferences proved possible thanks to the application of elements of the narrative (e.g. telling \& showing) and rhetoric (in order to discover the rhetorical figures used) methods, as well as and other tools. The results of my research lead to a decisive refutal of the critical appraisals of Nicodemus, and, by the same token, to dismiss the opinions expressed by the exegetes who not only in John 7, but also in John 19 see the character in a negative light and sternly criticise his respective words uttered and deeds performed for Jesus. Instead of reading him as an "ambiguous" character, we should evaluate Nicodemus's attitude as decisively positive.

The three episodes (John 3; 7; 19) show that Nicodemus gradually, as a result of an evolution of his position, grows mature enough to become a true follower of Jesus. ${ }^{127}$ Both him and Joseph prove themselves to be disciples, ${ }^{128}$ though the level of their discipleship will differ from that of familia Dei freshly constituted at the cross. In the women and the disciple whom Jesus loved we recognise constant adherence to Jesus, whereas these two Jewish dignitaries experience gradual growth in faith, they are in progress. Owing to that, they become the type of disciples who develop and continually strive to improve in their life of faith. Thus, their example appears to be even closer to the experience of the majority of Christians, who oftentimes fall down and require $\mu \varepsilon \tau$ óvor $\alpha$ ("change of mind / heart", "repentance", "regret"); therefore, for many they constitute the model disciple of Jesus, who develop courage and step out of hiding in order to publicly testify to their faith and their adherence to the Master. ${ }^{129}$ And even though they both transform for the better, it is Nicodemus - presented in three evangelical scenes - appears as a more distinct sign of that and a clearer role model. ${ }^{130} \mathrm{He}$ crowned his evangelical history of faith in Jesus with a public tribute paid to his Master as God's Prophet, Messiah, and the immortal King of glory.

127 Cf. a Lapide, Commentaria, 622; J.N. Suggit, "Nicodemus - The True Jew," Neot 14 (1980) 100; Tenney, "The Gospel of John," 186; Burge, John, 548; Vignolo, Personaggi, 118. The latter author defines the series of events occurring in Nicodemus's life as "the way of a disciple"; in his view it constitutes one of the "three typologies of faith [besides the Woman of Samaria and the royal official] ... composed in a crescendo manner" (ibidem, 94-95). Also Auwers, "Nuit," 503, states: "Plus que pour les autres personnages de l'évangile spirituel, la foi est pour Nicodème un chemin."

128 Cf. Aretius, Commentarii, 1032; Piscator, Commentarii, 715; Schlichting, Commentaria, 139; Bernard, John, 652; Westcott, John, 321; Brown, Death, 1267; M. Crimella, "Dal maestro alle comunità. Le comunità di Marco, Luca e Giovanni," PSV 61 (2010) 158-159.

129 Cf. Aretius, Commentarii, 1032; Keener, John, 1162; Brown, John, 960; J. Painter, "The Church and Israel in the Gospel of John: A Response," NTS 25 (1979) 112; Renz, "Nicodemus," 283; Auwers, "Nuit," 503.

130 Cf. P. Maranesi, La verità di Nicodemo. Racconto evangelico di un cammino di fede (Assisi: Cittadella 2019) 6-8. 


\section{Bibliography}

Aretius, B., In Novum Testamentum Domini nostri Iesu Christi Commentarii Doctissimi Benedicti Aretii Bernesis Theologi praestantissimi, facili perspicuaque methodo conscripti (Genevae: Apud Petrum et Iacobum Chouët 1618).

Ashton, J., Understanding the Fourth Gospel, 2 ed. (New York: Oxford University Press 2007).

Auwers, J.-M., "La nuit de Nicodème (Jean 3,2; 19,39) ou l'ombre du langage," Revue biblique 97 (1990) 481-503.

Barrett, C.K., The Gospel According to St. John. An Introduction with Commentary and Notes on the Greek Text (London: SPCK 1955).

Bassler, J.M., "Mixed Signals: Nicodemus in the Fourth Gospel," Journal of Biblical Literature 108 (1989) 635-646.

Bauckham, R., "Nicodemus and the Gurion Family," The Testimony of the Beloved Disciple. Narrative, History, and Theology in the Gospel of John, 3 ed. (ed. R. Bauckham) (Grand Rapids, MI: Baker Academic 2009) 137-172.

Bauer, W. - Danker, F.W. - Arndt, W.F. - Gingrich, F.W., A Greek-English Lexicon of the New Testament and Other Early Christian Literature, 3 ed. (Chicago - London: University of Chicago Press 2000).

Beasley-Murray, G.R., John, 2 ed. (Word Biblical Commentary 36; Nashville, TN: Word 1999).

Bennema, C., "Nicodemus: In the Twilight Zone," Encountering Jesus. Character Studies in the Gospel of John (ed. C. Bennema) (Minneapolis, MN: Fortress Press 2014) 147-160.

Bernard, J.H., A Critical and Exegetical Commentary on the Gospel According to St. John (International Critical Commentary 63; Edinburgh: Clark 1928) II.

Blank, J., Krisis. Untersuchungen zur johanneischen Christologie und Eschatologie (Freiburg im Breisgau: Lambertus 1964).

Blass, F. - Debrunner, A. - Rehkopf, F., Grammatik des neutestamentlichen Griechisch, 17 ed. (Göttingen: Vandenhoeck \& Ruprecht 1990).

Blinzler, J., Il processo di Gesù (trans. M.A. Colao Pellizzari) (Biblioteca di cultura religiosa 6; Brescia: Paideia 1966).

Blomberg, C.L., "The Globalization of Biblical Interpretation: A Test Case - John 3-4," Bulletin for Biblical Research 5 (1995) 1-15.

de Boer, M.C., "Johannine History and Johannine Theology: The Death of Jesus as the Exaltation and the Glorification of the Son of Man," The Death of Jesus in the Fourth Gospel (ed. G. Van Belle) (Bibliotheca Ephemeridum Theologicarum Lovaniensium 200; Leuven - Paris - Dudley, MA: Leuven University Press -Peeters 2007) 293-327.

Boughton, L.C., "The Priestly Perspective of the Johannine Trial Narrative," Revue biblique 110 (2003) 517-551.

Brant, J.-A.A., John (Grand Rapids, MI: Baker Academic 2011).

Brodie, T.L., The Gospel According to John. A Literary and Theological Commentary (New York Oxford: Oxford University Press 1993).

Brown, R.E., The Gospel According to John (XIII-XXI) (Anchor Bible 29A; Garden City, NY: Doubleday 1970).

Brown, R.E., The Community of the Beloved Disciple (New York - Mahwah, NJ: Paulist Press 1979). 
Brown, R.E., The Death of the Messiah. From Gethsemane to the Grave. A Commentary on the Passion Narratives in the Four Gospels (New York et al: Doubleday 1994) II.

Brown, T.G., Spirit in the Writings of John. Johannine Pneumatology in Social-scientific Perspective (Journal for the Study of the New Testament Supplement Series 253; London - New York: Clark 2003).

Bruce, F.F., The Gospel of John. Introduction, Exposition and Notes (Grand Rapids, MI: Eerdmans 1983).

Bruner, F.D., The Gospel of John. Commentary (Grand Rapids, MI - Cambridge: Eerdmans 2012).

Bultmann, R., Das Evangelium des Johannes, 16 ed. (Götingen: Vandenhoeck \& Ruprecht 1959).

Burge, G.M., John. From Biblical Text . . to Contemporary Life (NIV Application Commentary 4; Grand Rapids, MI: Zondervan 2000).

Burton, E. De Witt, Syntax of the Moods and Tenses in New Testament Greek (Edinburgh: Clark 1955). Chevallier, M.-A., 'La fondation de 'l'Église' dans le quatrième Évangile: Jn 19,25-30," Études théologiques et religieuses 58 (1983) 343-353.

Cignelli, L., "La grecità biblica," Liber Annuus Studii Biblici Franciscani 35 (1985) 203-248.

Cignelli, L. - Pierri, R., Sintassi di greco biblico (Lxx e NT). Quaderno I. A. Le concordanze (Studi Biblici Franciscani Analecta 61; Jerusalem: Franciscan Printing Press 2003).

Cipriani, S., "La questione giovannea. La singolare fisionomia del cosiddetto «Vangelo spirituale»," Cento problemi biblici (eds. G. Bressan et al.) (Assisi: Pro Civitate Christiana 1962) 312-324.

Clark-Soles, J., "Characters Who Count: The Case of Nicodemus," Engaging with C.H. Dodd on the Gospel of John. Sixty Years of Tradition and Interpretation (eds. T. Thatcher - C.H. Williams) (New York - Cambridge: Cambridge University Press 2013) 126-146.

Collins, R.F., These Things Have Been Written. Studies on the Fourth Gospel (Louvain Theological and Pastoral Monographs 2; Louvain: Peeters - Grand Rapids, MI: Eerdmans 1990).

Conway, C.M., Men and Women in the Fourth Gospel. Gender and Johannine characterization (Society of Biblical Literature Dissertation Series 167; Atlanta, GA: SBL 1999).

Cook, J.G., “Crucifixion and Burial,” New Testament Studies 57 (2011) 193-213.

Corley, K.E., "Women and the Crucifixion and Burial of Jesus," Forum 1 (1998) 181-225.

Cotterell, F.P., "The Nicodemus Conversation: A Fresh Appraisal," Expository Times 96 (1985) 237-242.

Countryman, L.W., The Mystical Way in the Fourth Gospel. Crossing over into God (Valley Forge, PA: Trinity Press International 1994).

Crimella, M., "Dal maestro alle comunità. Le comunità di Marco, Luca e Giovanni," Parola Spirito e Vita 61 (2010) 149-159.

Culpepper, R.A., Anatomy of the Fourth Gospel. A Study in Literary Design (Philadelphia, PA: Fortress 1983).

Culpepper, R.A., "Nicodemus: The Travail of New Birth," Character Studies in the Fourth Gospel. Narrative Approaches to Seventy Figures in John (eds. S.A. Hunt - D.F. Tolmie - R. Zimmermann) (Wissenschaftliche Untersuchungen zum Neuen Testament 314; Tübingen: Mohr Siebeck 2013) 249-259.

Davies, J., Death, Burial and Rebirth in the Religions of Antiquity (Religion in the First Christian Centuries; London - New York: Routledge 1999).

Davies, M., Rhetoric and Reference in the Fourth Gospel (Journal for the Study of the New Testament Supplement Series 69; Sheffield: JSOT Press 1992). 
Dietzfelbinger, Ch., Das Evangeliumnach Johannes, 2 ed. (Zürich: Theologischer Vorlag 2004) I-II.

Dodd, C.H., The Interpretation of the Fourth Gospel (Cambridge: Cambridge University Press 1968).

Donaldson, T.L., "Nicodemus: A Figure of Ambiguity in a Gospel of Certainty," Consensus 24 (1998) 121-124.

Draper, J.A., "What Did Isaiah See? Angelic Theophany in the Tomb in John 20:11-18," Neotestamentica 36 (2002) 63-76.

Dschulnigg, P., Jesus begegnen. Personen und ihre Bedeutung im Johannesevangelium (Theologie 30; Münster - Hamburg: LIT 2000).

Dschulnigg, P., "Nikodemus im Johannesevangelium," Studien zu Einleitungsfragen und zur Theologie und Exegese des Neuen Testaments. Gesammelte Aufsätze von Peter Dschulnigg (eds. B. Kowalski et. al.) (Biblical Tools and Studies 9; Leuven - Paris - Walpole, MA: Peeters 2010) 251-266.

Filtvedt, O.J., "Revisiting Nicodemus's Question in John 3:9," The Journal of Theological Studies 70 (2019) 110-140.

Flacius Illyricus, M., Glossa compendiaria in Novum Testamentum (Basileae: Perna \& Dietrich 1570).

Florit, E., Il metodo della "storia delle forme" e sua applicazione al racconto della Passione (Roma: Pontificio Istituto Biblico 1935).

Flusser, D. - Notley, R.S., The Sage from Galilee. Rediscovering Jesus 'Genius, 4 ed. (Grand Rapids, MI - Cambridge: Eerdmans 2007).

Friberg, B. - Friberg, T. - Miller, N.F., Analytical Lexicon of the Greek New Testament (Grand Rapids, MI: Baker Books 2000) [CD-ROM].

Gingrich, F.W., Shorter Lexicon of the Greek New Testament, 2 ed. (revised by F.W. Danker) (Chicago, IL - London: University of Chicago Press 1983).

Grasso, S., Il Vangelo di Giovanni. Commento esegetico e teologico (Roma: Città Nuova 2008).

Grochowski, Z., Il discepolo di Gesù nell'ora della prova (Gv 18-19), luogo di rivelazione del Maestro (Studia Biblica Lublinensia 13; Lublin: Wydawnictwo KUL 2015).

Grochowski, Z., “«Światłość w ciemności świeci i ciemność jej nie zaskoczyła / nie przyłapała». Narracyjne uzasadnienie nowego thumaczenia J 1,5," Studia Elblaskie 17 (2016) 119-133.

Grochowski, Z., “«Spirò» o piuttosto «consegnò lo Spirito»? La morte di Gesù e il dono del Paràclito presentati in Gv 19,28-30,” Studia Elbląskie 19 (2018) 291-303.

Gryglewicz, F., "Męka Chrystusa Pana w badaniach ostatnich dziesięciu lat," Ateneum Kapłańskie 63/1 (1971) 163-173.

Grappe, C., "Les nuits de Nicodème (Jn 3,1-21; 19,39). À la lumière de la symbolique baptismale et pascale du quatrième évangile," Revue d'histoire et de philosophie religieuses 87 (2007) 267-288.

Hakola, R., "The Burdenof Ambiguity: Nicodemus and the Social Identity of the Johannine Christians," New Testament Studies 55 (2009) 438-455.

Hastings, J. et al. (eds.), A Dictionary of the Bible. Dealing with Its Language, Literature, and Contents Including the Biblical Theology. III. Kir-Pleiades (Edinburgh: Clark 1904).

Heil, J.P., Blood and Water. The Death and Resurrection of Jesus in John 18-21 (Catholic Biblical Quarterly Monograph Series 27; Washington, DC: Catholic Bible Association of America 1995).

Hendriksen, W., Exposition of the Gospel Accordingto John. Two Volumes Complete in One, reprint (New Testament Commentary 4; Grand Rapids, MI: Baker Academic 2007).

Hengel, M., Crucifixion. In the Ancient World and the Folly of the Message of the Cross (Philadelphia, PA: Fortress 1977). 
Hunt, S.A., "Nicodemus, Lazarus, and the Fear of «The Jews» in the Fourth Gospel," Repetitions and Variations in the Fourth Gospel. Style, Text, Interpretation (eds. G. van Belle et. al.) (Bibliotheca Ephemeridum Theologicarum Lovaniensium 223; Leuven - Paris - Walpole, MA: Peeters 2009) 199-212.

Hylen, S.E., Imperfect Believers. Ambiguous Characters in the Gospel of John (Louisville, KY: Westminster John Knox 2009).

Ilan, T., Lexicon of Jewish Names in Late Antiquity. I. Palestine 330 BCE - 200 CE (Texts and Studies in Ancient Judaism 91; Tübingen: Mohr Siebeck 2002).

de Jonge, M., "Nicodemus and Jesus: Some Observations on Misunderstanding and Understanding in the Fourth Gospel," Bulletin of the John Rylands Library 53 (1971) 337-359.

Keener, C.S., The Gospel of John. A Commentary (Peabody, MA: Hendrickson 2003).

Kłósek, K., "Metoda analizy narracyjnej," Metody interpretacji Nowego Testamentu. Wprowadzenie (R. Bartnicki - K. Kłósek) (Kraków: Petrus 2014) 201-243, 278-284.

Knabenbauer, I., Commentarius in quatuor S. Evangelia Domini N. Iesu Christi. IV.Evangeliumsecundun Ioannem (Cursus Scipturae Sacrae 4; Parisiis: Lethielleux 1906).

Koester, C.R., "Theological Complexity and the Characterization of Nicodemus in the Gospel of John," Characters and Characterization in the Gospel of John (ed. C.W. Skinner) (London: Clark 2013) 165-181.

Köstenberger, A.J., John (Baker Exegetical Commentary on the New Testament 4; Grand Rapids, MI: Baker Academic 2004).

Kselman, J.S. - Barré, M.L., "Psalms," The New Jerome Biblical Commentary (eds. R.E. Brown J.A. Fitzmyer - R.E. Murphy) (London: Geoffrey Chapman 2000) 523-552.

Kubiś, A., "Zechariah 6:12-13 as the Referent of $\gamma \rho \alpha \varphi \eta$ in John 2:22 and 20:9. A Contribution to Johannine Temple-Christology," Biblical Annals 2 (2012) 153-194.

Kubiś, A., "Uniwersalny wymiar miłości Boga według J 3,16," Verbum Vitae 23 (2013) 127-160.

Kysar, R., John (Augsburg Commentary on the New Testament 4; Minneapolis, MN: Augsburg 1986). Lagrange, M.-J., Évangile selon Saint Jean (Études bibliques; Paris: Gabalda 1927).

a Lapide, C., Commentaria in Scripturam Sacram. XVI. In SS. Lucam et Joannem. Accurate recognovit ac notis illustravit Augustinus Crampon (Parisium: Vivés 1865).

Lausberg, H., Elementi di retorica (trans. L.R. Santini) (Bologna: Mulino 1987).

Lausberg, H., Retoryka literacka. Podstawy wiedzy o literaturze (trans. A. Gorzkowski) (Bydgoszcz: Homini 2002).

Liddell, H.G. - Scott, R. - Jones, H.S. - Mc Kenzie, R., A Greek-English Lexicon. With a Revised Supplement (Oxford, NY: Clarendon 1996).

Lincoln, A.T., The Gospel According to Saint John, 2 ed. (Black's New Testament Commentaries 4; Peabody, MA: Continuum 2006).

Lindars, B., The Gospel of John (New Century Biblical Commentary; Grand Rapids, MI: Eerdmans - London: Marshall, Morgan \& Scott 1981).

Lingad, C.G., The Problems of Jewish Christians in the Johannine Community (Tesi Gregoriana, Serie Teologia 73; Roma: Pontificia Università Gregoriana 2001).

Louw, J.P. - Nida, E.A. (eds.), Greek-English Lexicon of the New Testament based on Semantic Domains. I. Introduction and Domains, 3 ed. (New York: United Bible Societes 1989).

Manns, F., Ecce Homo. Una lettura ebraica dei Vangeli (Torino: Lindau 2011). 
Maranesi, P., La verità di Nicodemo. Racconto evangelico di un cammino di fede (Assisi: Cittadella 2019).

Marchadour, A., I personaggi del Vangelo di Giovanni. Specchio per una cristologia narrativa (ed. A. Filippi; trans. R. Pusceddu) (Bologna: Dehoniane 2007).

Marchese, A., Dizionario di retorica e di stilistica. Arte e artificio nell'uso delle parole. Retorica, stilistica, metrica, teoria della letteratura, 5 ed. (Milano: Mondadori 1985).

Mariano, C., Tetelestai. Il significato della morte di Gesù alla luce del compimento della Scrittura in Gv 19,16b-37 (Quaderni della Rivista di scienze religiose 14; Monopoli: Viverein 2010).

Mateos, J., El aspecto verbal en el Nuevo Testamento (Studios de Nuevo Testamento 1; Madrid: Ediciones Cristiandad - Valencia: Institución S. Jerónimo 1977).

Mateos, J. - Barreto, J., El Evangelio de Juan. Analisis lingüistico y comentario exegetico, 2 ed. (Madrid: Cristiandad 1982).

Mędala, S., Ewangelia wedtug świętego Jana. I. Rozdziały 1-12 (Nowy Komentarz Biblijny. Nowy Testament 4/1; Częstochowa: Edycja Świętego Pawła 2010).

Meeks, W.M., "The Man from Heaven in Johannine Sectarianism," The Interpretation of John (ed. J. Ashton) (Issues in Religion and Theology 9; Philadelphia, PA: Fortress - London: SPCK 1986) 141-173.

Mendner, S., "Nikodemus,” Journal of Biblical Literature 77 (1958) 293-323.

Metzner, R., Die Prominenten im Neuen Testament. Ein prosopographischer Kommentar (Studien zur Umwelt des Neuen Testaments 66; Göttingen: Vandenhoeck \& Ruprecht 2008).

Michel, M., "Nicodème ou le non-lieu de la vérité," Revue des sciences religieuses 55 (1981) 227-236.

Moloney, F.J., The Gospel of John (Sacra Pagina 4; Collegeville, MN: Liturgical Press 1998).

Morris, L., Reflections on the Gospel of John. Crucified and Risen (John 17-21) (Grand Rapids, MI: Baker Pub Group 1988) IV.

Moulton, J.H. - Milligan, G., The Vocabulary of the Greek Testament. Illustrated from the Papyri and Other Non-Literary Sources (Grand Rapids, MI: Eerdmans 1976).

Moulton, J.H. - Turner, N., A Grammar of New Testament Greek. III. Syntax (Edinburgh: Clark 1998).

Munro, W., "The Pharisee and the Samaritan in John: Polar or Parallel?," Catholic Biblical Quarterly 57 (1995) 710-728.

Murphy-O'Connor, J., “The Descent from the Cross and the Burial of Jesus (John 19:31-42)," Revue biblique 118 (2011) 533-557.

Neyrey, J.H., The Gospel of John (New Cambridge Bible Commentary; Cambridge: Cambridge University Press 2007).

O'Day, G.R., Revelation in the Fourth Gospel. Narrative Mode and Theological Claim (Philadelphia, PA: Fortress 1986).

Painter, J., "The Church and Israel in the Gospel of John: A Response," New Testament Studies 25 (1979) 103-112.

Pamment, M., "Focus in the Fourth Gospel," Expository Times 97 (1986) 71-75.

Pancaro, S., "The Metamorphosis of a Legal Principle in the Fourth Gospel. A Closer Look at John 7,51," Biblica 53 (1972) 340-361.

Pazdan, M.M., "Nicodemus and the Samaritan Woman: Contrasting Models of Discipleship," Biblical Theology Bulletin 17 (1987) 145-148.

Piscator, J., Commentarii in omnes libros Novi Testamenti (Herbornae Nassoviorum: [s.n.] 1638). 
Piwowar, A., Składnia języka greckiego Nowego Testamentu (Materiały Pomocnicze do Wykładów z Biblistyki 13; Lublin: Wydawnictwo KUL 2017).

Rahmani, L.Y., A Catalogue of Jewish Ossuaries in the Collections of the State of Israel (Jerusalem: Israel Antiquities Authority - Israel Academy of Sciences and Humanities 1994).

Renz, G., "Nicodemus: An Ambiguous Disciple? A Narrative Sensitive Investigation," Challenging Perspectives on the Gospel of John (ed. J. Lierman) (Wissenschaftliche Untersuchungen zum Neuen Testament 2/219; Tübingen: Mohr Siebeck 2006) 255-283.

Resseguie, J.L., The Strange Gospel. Narrative Design and Point of View in John (Biblical Interpretation 56; Leiden - Boston - Köln: Brill 2001).

Ridderbos, H.N., The Gospel of John. A Theological Commentary (Grand Rapids, MI: Eerdmans 1997).

Rigato, M.-L., Il Titolo della Croce di Gesù. Confronto tra i Vangeli e la Tavoletta-reliquia della Basilica Eleniana a Roma (Tesi Gregoriana, Serie Teologia 100; Roma: Pontificia Università Gregoriana 2003).

Robinson, J.A.T., The Priority of John (London: SCM 1985).

Rosik, M., "Discovering the Secrets of God's Gardens. Resurrection as New Creation (Gen 2:4b-3:24; John 20:1-18)," Liber Annuus Studii Biblici Franciscani 58 (2008) 81-98.

Sabbe, M., "The Johannine Account of the Death of Jesus and its Synoptic Parallels (John 19,16b-42)," Ephemerides theologicae Lovanienses 70 (1994) 34-64.

Safrai, Z., "Nakdimon b. Guryon: A Galilean Aristocrat in Jerusalem," The Beginning of Christianity (eds. J. Pastor - M. Mor) (Jerusalem: Yad Ben-Zvi Press 2005) 297-314.

Schlichting J., Commentaria posthuma in plerosque Novi Testamenti libros (Irenopoli: Irenici Philalethii 1656).

Schnackenburg, R., Das Johannesevangelium. I. Einleitung und Kommentar zu Kap. 1-4 (Herders theologischer Kommentar zum Neuen Testament 4; Freiburg - Basel - Wien: Herder 1965).

Schnackenburg, R., Das Johannesevangelium. III. Kommentar zu Kap. 13-21 (Herders theologische Kommentar zum Neuen Testament 4; Freiburg - Basel - Wien: Herder 1975).

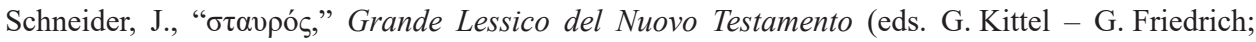
Italian eds. F. Montagnini - G. Scarpat - O. Soffritti) (Brescia: Paideia 1979) XII, 969-991.

Sevrin, J.-M., "The Nicodemus Enigma: The Characterization and Function of an Ambiguous Actor of the Fourth Gospel," Anti-Judaism and the Fourth Gospel. Papers of the Leuven Colloquium 2000 (ed. R. Bieringer - D. Pollefeyt - F. Vandecasteele-Vanneuville) (Jewish and Christian Heritage 1; Assen: Royal Van Gorcum 2001) 357-369.

Smyth, H.W., Greek Grammar (Cambridge, MA: Harvard University Press 1984).

Staley, J.L., "Subversive Narrator/Victimized Reader: A Reader Response Assessment of a Text-Critical Problem, John 18.12-24," Journal for the Study of the New Testament 51 (1993) 79-98.

Stibbe, M.W.G, "The Elusive Christ: A New Reading of the Fourth Gospel," Journal for the Study of the New Testament 44 (1991) 19-38.

Strack, H.L. - Billerbeck, P., Kommentar zum Neuen Testament aus Talmud und Midrasch. II. Das Evangelium nach Markus, Lukas und Johannes und die Apostelgeschichte. Erläutert aus Talmud und Midrasch (München: Beck 1961).

Suggit, J.N., "Nicodemus - The True Jew," Neotestamentica 14 (1980) 90-110.

Sylva, D.D., "Nicodemus and his Spices (John 19.39)," New Testament Studies 34 (1988) 148-151. 
Tenney, M.C., "The Gospel of John,” The Expositor's Bible Commentary with the New International Version of the Holy Bible. IX. John-Acts (eds. F.E. Gaebelein - J.D. Douglas) (Grand Rapids, MI: Zondervan 1981) 1-203.

Thayer, J.H., A Greek-English Lexicon of the New Testament Being Grimm's Wilke's Clavis Novi Testamenti, 24 ed. (Grand Rapids, MI: Baker Book 1999).

Thyen, H., Das Johannesevangelium (Handbuchzum Neuen Testament 6; Tübingen: Mohr Siebeck 2005).

Tsuchido, K., "The Composition of the Nicodemus-Episode, John ii 23 - iii 21," Annual of the Japanese Biblical Institute 1 (1975) 91-103.

Vanhoye, A., "Opisy Męki w Ewangeliach synoptycznych," Męka wedtug czterech Ewangelii (eds. A. Vanhoye et al.; trans. E. Romanek) (Kraków: Kairos 2002) 11-66.

Vignolo, R., Personaggi del Quarto Vangelo. Figure della fede in San Giovanni, 2 ed. (Milano: Glossa 2006).

von Wahlde, U.C., The Gospel and Letters of John. II. Commentary on the Gospel of John (Eerdmans Critical Commentary; Grand Rapids MI - Cambridge: Eerdmans 2010).

Wallace, D.B., Greek Grammar Beyond the Basics. An Exegetical Syntax of the New Testament with Scripture, Subject, and Greek Word Indexes (Grand Rapids, MI: Zondervan 1996).

Wengst, K., Il vangelo di Giovanni (Italian ed. G. Boscolo; trans. C. Danna) (Brescia: Queriniana 2005).

Westcott, A., The Gospel According to St. John. The Greek Text with Introduction and Notes, by late Brooke Foss Westcott (Thornapple Commentaries 4; Grand Rapids, MI: Baker Book House 1980) II.

Whitenton, M.R., "The Dissembler of John 3: A Cognitive and Rhetorical Approach to the Characterization of Nicodemus," Journal of Biblical Literature 135 (2016) 141-158.

Whitenton, M.R., Configuring Nicodemus. An Interdisciplinary Approach to Complex Characterization (Library of New Testament Studies 549; London: Clark 2019).

Witczyk, H., "Historia w ewangelicznych świadectwach o Męce i Śmierci Jezusa," Jezus i Ewangelie w ogniu dyskusji. Od H. Reimarusa do T. Polaka (eds. J. Kudasiewicz - H. Witczyk) (Biblioteka "Verbum Vitae" 2; Kielce: Instytut Teologii Biblijnej "Verbum" 2011) 225-288.

Zahn, T., Das Evangelium des Johannes, 6 ed. (Kommentar zum Neuen Testament 4; Leipzig: Deichert 1921).

Zangenberg, J., "«Buried according to the Customs of the Jews». John 19,40 in Its Material and Literary Context," The Death of Jesus in the Fourth Gospel (ed. G. van Belle) (Bibliotheca Ephemeridum Theologicarum Lovaniensium 200; Leuven - Paris - Dudley, MA: Leuven University Press -Peeters 2007) 873-900.

Zerwick, M., Biblical Greek Illustrated by Examples (Scripta Pontificii Instituti Biblici 114; Roma: PIB 2001).

Zlotnick, D. - Kutscher, E.Y., The Tractate “Mourning”. Śěmahot. Regulations Relating To Death, Burial, and Mourning. Translated from the Hebrew With Introduction and Notes by Dov Zlotnick. With Hebrew Text Vocalized by E. Y. Kutscher (Yale Judaica Series 17; New Haven, CT: Yale University Press 1966).

Zumstein, J., L'évangile selon saint Jean (13-21) (Commentaire du Nouveau Testament 4b; Genève: Labor et Fides 2007).

Zumstein, J., L'évangile selon saint Jean (1-12) (Commentaire du Nouveau Testament 4a; Genève: Labor et Fides 2014). 